Proceedings of the American Academy of Arts and Sciences. Vol. 52, No. 1. - June, 1916.

CONTRIBUTIONS FROM THE CRYPTOGAMIC LABORATORIES OF HARVARD UNIVERSITY. No. LXXVIII.

NEW OR CRITICAL SPECIES OF CHITONOMYCES AND RICKIA.

By Roland Thaxter. 



\title{
NEW OR CRITICAL SPECIES OF CHITONOMYCES AND RICKIA.
}

\author{
By Roland Thaxter.
}

\author{
Presented May 10, 1916. Received March 28, 1916.
}

THE new forms herein described are, with few exceptions, parasites of tropical hosts which have been collected for me through the kindness of the Rev. George Schwab in Kamerun, Mr. J. C. Moulton in Borneo, and Mr. Oakes Ames and Mr. C. S. Banks in the Philippines. The West Indian forms were for the most part collected by myself; a few, together with certain Central American hosts, having been examined in the collections of the Museum of Comparative Zoölogy at Cambridge, through the courtesy of Mr. Samuel Henshaw.

Since the paper deals with two genera, only, it is hardly necessary to remark that it includes only a portion of the novelties thus obtained, further additions to which will be published later. I desire again in this connection to acknowledge my obligations to the gentlemen above mentioned, as well as to Mr. Gilbert A. Arrow, of the British Museum, who has been so kind as to determine for me numerous coleopterous hosts.

\section{Chitonomyces.}

Since the cell-number and arrangement in a majority of the species in this genus are more or less definite, it has seemed best in the following diagnoses to letter the successive cells as follows: The basal cell $a$, the subbasal $b$. The latter is usually followed by three cells which normally form a series horizontally disposed, the anterior $c$, the median $d$, and the posterior $e$. The relative position of these cells may, however, vary considerably, and the anterior may become much reduced in size and lie above cells $d$ and $e$. Of the posterior cells which lie normally beside the perithecium, the lowest, and usually the longest, is distinguished as cell $f$, the distal end of which is separated by a septum to form the small appendiculate cell $h$, external to 
which cell $g$ bears distally the terminal free appendiculate cell $i$, from which the primary appendage arises terminally. On hosts belonging to genera other than Laccophilus several species occur in which no septum separates cell $f$ from cell $h$, so that the pointed end of the former itself bears the appendage, which arises next the perithecium; while the latter is not distinguished as a distinct cell.

In addition to the new forms on Laccophili from the West Indies enumerated below the following were also met with.

Chitonomyces hyalinus Th. A form hardly separable from this species was found at Sangre Grande, Trinidad. Its general habit is distinctly more slender than that of the type, especially the basal portion of the receptacle and cell $i$. The elevation which subtends the apex of the perithecium, and projects somewhat inward on the right side, is also distinctly more prominent. Otherwise it shows no essential differences. A form smaller and somewhat stouter than the type was also found at the Grand Etang, Grenada. Both these forms occur on the posterior legs.

C. psittacopsis Th., resembling the type in all respects was found commonly both in Trinidad and at the Grand Etang on a single species of Laccophilus, Nos. 2687 and 2684.

C. appendiculatus Th., agreeing essentially with the type, was found at Sangre Grande, near the base of the left elytron of a single individual of Laccophilus, No. 2680.

C. simplex Th., exactly resembling the type and growing in the same position, was found rarely at Sangre Grande, No. 2684.

C. paradoxus Peyr., showing a considerable degree of variation both in color and in the conformation of the tip of the perithecium, was found commonly on three species of Laccophilus in Grenada and Trinidad.

C. rhyncostoma Th., was found on a peculiar Laccophilus in the Arepo Savanna, at Cumuto, Trinidad, and showed no essential differences from the type.

C. distortus Th., growing in the usual position on the front legs, was found rarely at the Grand Etang and varies slightly from the type.

C. uncinatus Th., somewhat larger and more slender, was found rarely at the Grand Etang and also at Sangre Grande. In the Trinidad material the basal cell of this species tends to become conspicuously blackened, and the projection of cell $g$ is appressed against the adjacent tip of the perithecium. The longest individual measures $175 \mu$.

C. marginatus Th. A form agreeing in all respects with the type was found on two individuals of Laccophilus at the Grand Etang. 
C. dentiferus Th. A form closely resembling this species, and in which the base, only, of the tooth-like perithecial appendage is developed, was found on several specimens of Laccophilus, No. 2680, from Sangre Grande. The slender termination of the perithecium is usually rather irregularly bent outward and then inward at the apex, the whole distal portion sometimes erect, and sometimes bent partly across the distal cells of the receptacle. On the right side of cell $g$, are two superposed dark tubercular patches which occupy most of the surface on this side. These patches are not always very conspicuous, but are present in the type of dentiferus, although they were overlooked in the original description and figures.

C. Hydropori Th. A form not distinguishable from the types of this species was found on a species of Hydroporus? from Manila, P. I.

\section{Chitonomyces cerviculatus nov. sp.}

Rather short, subsigmoid when viewed sidewise, uniformly tinged with dirty yellowish brown, with certain deeper amber-brown suffusions. Foot large; basal cell short and stout, somewhat longer than broad; cell $b$ about twice as broad as long, horizontal, more strongly convex on one side; cells $c, d$ and $e$ small and subequal, subtriangular, dissimilar; cell $d$ somewhat larger; cell $f$ tapering to a very narrow base, lying almost wholly above cell $e$, and becoming much broader distally; where it is slightly and symmetrically intruded between the small narrowly triangular cell $h$, and cell $i$, which is distorted by an umbonate prominence, on the right side, that throws the insertion of cell $i$ asymmetrically to the left, so that it may be sublateral in position; cell $i$ symmetrical, broadly subhemispherical, the insertion of the primary appendage terminal. A short stout spiral appendage is present, arising on the right side, within and near the apex of cell $h$. Perithecium relatively large, irregularly subsigmoid; the outer margin of the venter concave, amber-brown, its distal end bulging abruptly on the left side below the stout, neck-like, strongly incurved terminal portion; which is of nearly uniform width to the apex, slightly broader below; the subterminal wall-cell, on the outer side, forming an amberbrown, somewhat appressed and distally outcurved appendage; which is sometimes subsymmetrical with the thick, dark amber margin of the opposite side; the apex broad, somewhat asymmetrically rounded, bent inward; the hyaline lips slightly prominent. Spores about $36 \times 2.5 \mu$. Perithecia, body $45-50 \times 18 \mu$, the neck 
$35 \times 12 \mu$. Cell $i 5.5 \times 9 \mu$. Total length to tip of perithecium $90-100 \times 23-27 \mu$.

On the outer edge of the right elytron of Laccophilus sp., near the middle. Grand Etang, Grenada, No. 2687, and Sangre Grande, Trinidad, B. W. I., No. 2684.

A peculiarly distorted form, well distinguished by its two appendages and the stout neck-like termination of its perithecium.

\section{Chitonomyces introversus nov. sp.}

Distally flat and broad, becoming roughly triangular in outline, rather evenly suffused with dull amber brown; basal cell relatively large, curved below, much broader distally; cell $b$ horizontal, greatly flattened; cell $c$ very small; cell $d$ broad and flattened; cell $e$ somewhat larger, subtriangular, obliquely separated from cell $f$, which is long and narrow; its lumen, which is abruptly broader distally, otherwise nearly obliterated by the unusual thickness of the outer wall; the rest of the receptacle turned abruptly inward so that it lies sometimes almost at right angles to the general vertical axis; cell $g$ relatively long, its base posterior, its upper (outer) margin more or less distinctly concave; cell $h$ more than half as long, also lying obliquely or subhorizontally; cell $i$ paler, slightly longer than broad, its inner (lower) side flattened and lying just above a shelf-like prominence that subtends the tip on the left side of the perithecium. The latter broad and short, its tip short, bent abruptly to the right away from the subtending prominence; so that, when the perithecium lies at the right, it is viewed end on; the apex irregularly rather coarsely lobed. Spores lying nearly horizontally in the upper part of the perithecium about $36 \times 3.6 \mu$. Body of the perithecium, exclusive of tip, 54-60 $\times$ $27-32 \mu$. Total length $80-95 \mu$; the three lateral dimensions $40 \times 75$ $\times 82-50 \times 86 \times 90 \mu$.

On the posterior legs of Laccophilus sp. No. 2687, Grand Etang, Grenada, B. W. I.

A rare species easily distinguished by its triangular form and the horizontal position of cells $g-i$.

\section{Chitonomyces oedipus nov. sp.}

More or less deeply and uniformly tinged with dull amber-brown; short and stout. Basal cell inflated below; the inflated portion some- 
what resembling the human ear in outline, convex below, its axis horizontal, bearing the foot on its flat upper margin, near one end of which the short distal portion of the cell, narrow below and abruptly broader above, arises; cell $b$ small, flattened, horizontal, somewhat irregular, producing a more or less well developed outgrowth from its anterior margin, which may project outward horizontally or grow downward against the termination of the basal cell, from which it may appear to arise; cells $c, d$ and $e$ small, flattened, irregular and confused with one of the persistent basal cells of the perithecium; cell $e$ smaller, subtriangular, separated from cell $b$ by the whole width of cell $d$; marginal region evenly convex; cell $f$ long, narrowing below to its oblique base, distally somewhat overlapped by cell $g$, which is larger than cell $h$; cell $i$ longer than broad, tapering to its rounded extremity, strongly curved inward so as slightly to overlap the tip of the perithecium, thus making the primary appendage horizontal in position. Perithecium relatively large and stout; the outer margin nearly straight; a variably developed rounded elevation projecting externally near its base; the short abruptly distinguished tip bent to the right, then outward; subtended externally by a variably developed erect outgrowth, which tapers to a blunt point and may exceed the somewhat irregular apex, which is slightly compressed about the pore; a long, straight, curved or subsigmoid, more deeply colored, divergent, then erect appendage, tapering from a broad base to a sharply pointed or somewhat blunt, attenuated apex, arises from one of the wall-cells close beside the end of cell $h$ on the right side, and extends some distance above the apex of the perithecium. Spores about $40 \times 4 \mu$. Perithecia $72 \times 30 \mu$; the outer spine $21-26 \mu$, the inner 45-55 $\mu$; inflated part of basal cell $36 \times 23 \mu$. Total length to tip of perithecium $100-120 \times 35 \mu$.

Growing singly between the terminal claws of the posterior legs of Laccophilus sp.; Sangre Grande, Trinidad, B. W. I., No. 2684, and the Grand Etang, Grenada, No. 2687.

A very peculiar species, at once distinguished by its swollen base, which is evidently an adjustment to its peculiar habitat, and by its perithecial appendages.

\section{Chitonomyces Grenadae nov. sp.}

Tinged with dirty brownish, rather irregularly developed. Basal cell longer than broad; cell $b$ somewhat flattened, horizontal, more or less clearly distinguished above and below by constrictions; cells $c, d$ 
and $e$ irregularly disposed, small; cell $f$ long and narrow, its base but slightly oblique, its distal end but slightly overlapped by cell $g$ which projects a short distance free above cell $h$; cell $i$ more deeply suffused, sometimes amber-brown, long and stout, nearly straight or usually variously and slightly bent, its basal septum horizontal, its tip asymmetrical, the apex turned inward, of nearly the same diameter throughout, extending for about half its length above the extremity of the perithecium. Perithecium somewhat misshapen; tapering to the base, where it is subtended by a distinct constriction; the second external wall-cell forming a thick amber-brown margin, becoming broader and ending in a more or less pronounced elevation, distally, which subtends a second slight elevation followed by a constriction, above which the tip is irregularly bent inward and to one side; the apex blunt, with large slightly prominent lip-cells. A variably developed appendage arises from the wall-cell on the left side, next the end of cell $h$, sometimes quite short, normally longer, somewhat inflated, distally recurved and pointed. Spores about $36 \times 2 \mu$. Perithecia $55-60 \times 14 \mu$. Cell $i 28-30 \times 7 \mu$. Total length to tip of perithecium $70-75 \times 20-22 \mu$.

On the margin of the right elytron of Laccophilus sp. near the tip. Grand Etang, Grenada, B. W. I., No. 2687a.

Most nearly related to $C$. rhyncostoma, from which it differs in many respects, but more particularly in the relatively much shorter free portion of cell $g$, and by the distorted tip of its perithecium. It was not observed on any of the very numerous individuals of the same host collected in Trinidad.

\section{Chitonomyces uncinulatus nov. sp.}

Uniform pale dirty yellowish brown, regularly curved throughout, almost crescent shaped. Basal cell rather stout, tapering considerably below; cell $b$ about twice as broad as long, horizontal, the anterior margin slightly concave, the posterior convex; cells $c, d$ and $e$ subequal, the base of cell $c$ in contact with cell $b$; cell $f$ very long and narrow, its base only slightly oblique, distally slightly and symmetrically intruded between cells $g$ and $h$, cell $h$ extending free some distance above the apex of cell $g$, and bent so as partly to overlap the perithecium; cell $i$ longer than broad, distally rounded, and terminated by the dark insertion of the appendage. Perithecium long, curved outward, and tapering evenly to a blunt apex; the outer margin slightly indented 
at the junction of the wall-cells; a long irregularly curved, slender, darker appendage, ending in an abrupt bluntly pointed hook and developed from one of the wall-cells, diverges irregularly from a point beside the apex of cell $h$. Spores about $35 \times 2 \mu$. Perithecium $72 \times$ $18 \mu$; its appendage about $24-30 \times 3.5 \mu$. Total length to tip of perithecium $100-120 \times 27 \mu$.

On the margin of the right elytron of Laccophilus sp. near the middle; Sangre Grande, Trinidad, B. W. I., No. 2680.

This species is well distinguished by its falcate habit, and the long, hooked or subhelicoid appendage which arises from a point near the apex of cell $h$. It is a singular fact that the two other species which possess a somewhat similar appendage similarly placed, namely $C$. rhyncostoma and C. cerviculatus, although otherwise quite different, occupy a similar position on the host.

\section{Chitonomyces manubriolatus nov. sp.}

Rather short and stout, subsigmoid in habit, amber-yellow, becoming rather deeply tinged with amber-brown. Basal cell short, subtriangular, abruptly bent, obliquely separated from cell $b$, which overlaps it for nearly half its length on its posterior, convex, side; cell $b$ similar or somewhat smaller, together with the three cells above it, more deeply tinged with clear amber-brown: cell $c$ irregularly triangular, broader than cells $d$ or $e$; cell $d$ reaching to the posterior margin for a short distance below cell $e$, which is thus wholly separated from cell $b$; cell $e$ flat, oblique, its transverse axis uniform throughout; cell $f$ but slightly narrower below, externally concave, obliquely separated from cells $e$ and $g$, sometimes hardly twice as long as broad; cell $g$ externally convex, prolonged distally and externally to form a large, free, deep amber-brown appendage, which may exceed the tip of the perithecium, is suberect or variably divergent, projecting free from the posterior margin, straight or irregularly bent below, narrowed at the base, above which it is rather abruptly swollen, and tapering thence to its blunt apex; cell $h$ normal in form and position; cell $i$ nearly hyaline, tapering somewhat to its rounded extremity, subsymmetrical, erect, about twice as long as broad, or less. Perithecium strongly convex externally, the outline of its margin not quite even, owing to slight indentations at the junction of the wall-cells; the tip somewhat distinguished, curved inward, short, stout, the outer lip-cell forming a rounded prominence, the inner broad and flat, the lateral ones 
symmetrically prominent. Spores about $40 \times 3.5 \mu$. Perithecium $75-85 \times 27 \mu$, its appendage about $45 \times 11 \mu$. Total length to tip of perithecium $125-145 \times 40-45 \mu$.

On the posterior legs of Laccophilus sp., Sangre Grande, Trinidad, B. W. I., No. 2684; and Grand Etang, Grenada, No. 2687.

A peculiar species resembling $C$. spinosus and $C$. Italicus in having a well developed appendage arising from cell $g$.

\section{Chitonomyces helicoferus nov. sp.}

General color clear pale straw-yellow; the axis nearly straight. Basal cell hardly twice as long as broad, tapering slightly to the relatively small foot; cell $b$ about as long as cell $a$, its anterior margin slightly concave; cells $c . d$ and $e$ relatively long, subequal, the base of cell $d$ occupying the whole distal margin of cell $b$; cell $c$ usually prominently convex above cell $b$; cell $f$ rather long and narrow, its base somewhat oblique; cells $g$ and $h$ subequal, the former dark amberbrown distally; cell $i$ prolonged far beyond the insertion of the appendage, which becomes lateral in position on the inner side, where the base of the proliferation forms a slight angle; the cell-insertion blackish; the cell proper hyaline; the proliferation divergent, tapering, blackish olive, its sharp apex recurved in an abrupt helix of one turn. Perithecium narrower below, its outer margin evenly convex; the flaring tip abruptly distinguished by a dark amber-brown, erect, finger-like projection, appressed and extending to the small hyaline blunt apex, which it partly conceals; the inner subterminal wall-cell subtriangular, projecting on the inner side to form a divergent, bluntly subconical process; the lower margin of which lies close beside cell $i$, and part of its proliferation. Spores about $25 \times 2 \mu$. Perithecia $54-60 \times 12.6 \mu$; anterior projection $14 \times 5 \mu$, the posterior $18 \mu$, by $18 \mu$ at base. Total length to tip of perithecium $100 \times 19 \mu$.

On the margin of the left elytron near the middle, of Laccophilus sp.; No. 2680, Sangre Grande, Trinidad, B. W. I.

A very characteristic species, most nearly related to $C$. melanurus, from which it is most readily distinguished by the modification of cell $i$, the proliferation of which is quite different in shape and color, while the cell itself is hyaline instead of opaque. A dozen well developed and perfect specimens have been examined. 


\section{Chitonomyces bicolor nov. sp.}

Hyaline or becoming faintly tinged with dirty yellowish brown, except the large opaque terminal cell. Foot sharply pointed and basally swollen. Basal cell two or three times longer than broad, tapering somewhat to its base; cell $b$ small, flattened, horizontal; cells $c, d$ and $e$ subequal; cell $d$ an isosceles triangle, pointed above; cells $c$ and $e$ subtriangular and similar, cell $e$ somewhat larger; cell $f$ long and narrow, its base extending downward external to cell $e$ for less than half the latter's length; cell $g$ somewhat broader than cell $h$, its base slightly overlapping the termination of cell $f$; cell $i$ extending to, or slightly higher than, the apex of the perithecium, free, blackish, somewhat translucent, opaque externally and distally, abruptly and more or less strongly curved outward distally, the convex margin roughened or tuberculate. Perithecium externally rather strongly convex below, tapering somewhat, distally, to the broadly spreading asymmetrical termination; which is outwardly prominent and rounded, and may be suffused; a much more prominent free rounded projection directed inward, and often wholly or partly overlapping cell $i$; a slight median papillate projection also arises near the pore. Spores about $24 \times 2 \mu$. Perithecia $60-80 \times 12-14 \mu$. Cell $i$ about $30-7 \mu$. Total length to tip of perithecium $100-125 \mu$.

On the outer margin of the left elytron of Laccophilus sp., Sangre Grande, Trinidad, No. 2684; and on the same species at the Grand Etang, Grenada, B. W. I., No. 2687.

A species most nearly allied to $C$. Javanicus, but distinguished especially by the different modification of cell $i$, the opacity of which does not involve cell $g$, as in the Javan species.

\section{Chitonomyces seticolus nov. sp.}

Basal cell about twice as long as broad, slightly broader distally; cell $b$ horizontal, broader than long, distinguished above and below by well defined constrictions: cells $c$ and $d$ small, subequal, the latter an isosceles triangle, distally pointed; cell $e$ somewhat larger and obliquely adjusted to the base of cell $f$, which extends more than half way to its base: the remaining cells all becoming opaque, or nearly so, forming a black-brown margin to the perithecium, externally symmetrically convex, somewhat translucent along its inner edge, and rather 
closely rugose; the rugosity hardly distinguishable at maturity, but indicated by faint transverse darker lines; the whole dark area continuous with cell $i$, which curves slightly against the tip of the perithecium which it more or less completely conceals; its basal septum indicated by a darker transverse line, its apex abruptly narrowed to form a short curved finger-like projection which rises above the base of the laterally projecting primary appendage. Perithecium rather narrow, becoming yellowish, slightly concave near the base; the tip becoming abruptly narrowed to a hyaline, short, curved, neck-like termination; the apex bent, usually, toward cell $i$; the lip-cells rather prominent and asymmetrical. Spores about $25 \times 2 \mu$. Perithecia $50-60 \times 6 \mu$. Cell $i 12.5 \times 5.5 \mu$ not including its distal projection, which is $5 \times 3 \mu$.

Growing among the bristles just within the margin of the distal half of the left elytron of Laccophilus sp., No. 2687, Grand Etang, Grenada, B. W. I.

This species is closely allied to C. marginatus, which was found on one or two individuals from the same locality growing in its usual position on the wing-margin nearer the base. The present species differs in the presence of a series of closely set transverse ridges on cells $f$ to $h$, which, although they are clearly defined in young individuals, might readily escape notice in more mature specimens; and also in the form of cell $i$, which is much longer, and is terminated by a short, narrow, finger-like process; which, in $C$. marginatus, is replaced by a broad truncate extension, as long or longer than the body of the cell itself, from which it is also distinguished by a clearly defined transverse hyaline area.

\section{Chitonomyces striatus nov. sp.}

Minute and slender. Basal cell hardly larger than the relatively large foot, somewhat suffused with brown below, about the same diameter throughout, hardly twice as long as broad; cell $b$ horizontal, of about the same width, distinguished by slight indentations, about two thirds as long as broad; cells $c, d$ and $e$ subequal, the base of cell $c$ in contact with cell $b$; cell $d$, only, triangular; cell $e$ slightly larger, obliquely separated from cell $f$, and not in contact with cell $b$; cell $f$ relatively short, its rounded extremity obliquely and subsymmetrically separated from cells $g$ and $h$, which are nearly equal and as long or longer than cell $f$; the region included by cells $g$ and $h$, and the upper half of cell $f$, tinged with brownish and crossed, on the right side only, 
by seven or eight blackish horizontal parallel ridges, which extend beyond the middle of the adjacent venter of the perithecium, which is otherwise nearly hyaline; cell $i$ continuing the axis of cells $g$ and $h$ directly, erect, about twice as long as broad, distally hyaline and tapering slightly, suffused below, with several blackish flat tubercular patches, the blackened base of the appendage terminal. Perithecium relatively long, narrow and subsigmoid; tapering distally; the strongly convex outer margin uneven, owing to slight elevations which mark the junction of the lower wall-cells; the third external wall-cell producing from its base, a rather slender, very slightly curved, blunt appendage, which projects upward at an angle of more than $45^{\circ}$; the slender tip curved abruptly outward, and ending in a hood-like apex. Spore about $20 \times 1.5 \mu$. Perithecia $46-50 \times 10 \mu$, the appendage 9-10 $\times 2-2.5 \mu$. Total length to tip of perithecium $75-80 \times 16-17 \mu$.

On the superior prothorax of Laccophilus sp.; No. 2687, Grand Etang, Grenada, B. W. I.

This species is most nearly related to $C$. dentiferus among described species. It is distinguished from all other forms, however, by its conspicuous transverse blackish striations on the right side.

\section{Chitonomyces elongatus nov. sp.}

Long, slender, of nearly the same diameter from the basal cell to the base of the perithecial tip: evenly suffused with dirty yellowish or amber-brown; except the basal cell which is more deeply suffused, often blackened on one side and at the base, and also a deeply suffused region along the anterior margin of the tip of the perithecium which merges into a more or less distinct transversely mottled area extending half way across the tip on the right side. Basal cell rather long, convex along its suffused margin, obliquely separated from cell $b$ which it overlaps on one side almost completely, and by which it is overlapped for less than half its length on the opposite side; cells $d$ and $e$ relatively long, lying side by side, similar; cell $c$ small and overlapping the distal end, only, of cell $d$, for the most part on the left side; cell $f$ very long and narrow, its base somewhat oblique and but slightly overlapped by cell $g$, which is relatively long and narrow, slightly broader distally, and hardly longer than cell $h$; cell $i$ more than twice as long as broad, bent against the margin of the perithecium some distance below its apex. Perithecium very long and narrow, the tip hardly distinguished, except by its suffusion; the apex well distin- 
guished on the inner side, somewhat longer than broad, of the same diameter throughout, distally flattened or bluntly rounded, with slightly projecting lips around the median terminal pore. Spores $40 \times 2.5 \mu$. Perithecia $86-100 \times 10-12 \mu$. Cell $i 12 \times 5.5 \mu$. Total length to tip of perithecium 120-155 × 12-16 $\mu$.

On the tip of the right elytron of Laccophilus sp.; Sangre Grande, Trinidad, B. W. I., No. 2680 b.

Although this species is not marked by any of the bizarre characteristics so frequently met with in the genus, it does not seem closely allied to any species known to me. It is most clearly distinguished by its slender form, the obliquity of cell $b$, and by the mottled suffusion on one side of the tip of the perithecium.

\section{Chitonomyces longirostratus nov. sp.}

Pale straw-yellow. Foot small; basal cell more or less, often greatly elongated, becoming opaque; cell $b$ squarish, or longer than broad; cell $c$ similar to, or somewhat smaller than cell $b$; cells $d$ and $e$ separated from cell $b$ by the whole length of cell $c$, both small; cell $f$ long and narrow, its base hardly oblique, slightly overlapped by cell $g$; cell $i$ hyaline, four times longer than broad, the apex slightly asymmetrical. Perithecium subclavate, strongly curved sidewise, the tip abruptly distinguished, enormously elongated, opaque on one side, translucent purplish brown on the other, of about the same diameter throughout, perfectly straight and rigid; the apex short, distinguished on one side; the lips hyaline and somewhat prominent. Spores about $30 \times 2 \mu$. Perithecia, body $65-78 \times 18-20 \mu$, the tip $245-260 \times 8-$ $11 \mu$. Total length, to base of perithecial tip, 140-156 $\mu$.

On the outer margin, at the tip, of the right elytron of Laccophilus sp., Sangre Grande, Trinidad, B. W. I., No. 2680a.

A most peculiar species, clearly distinguished by the extraordinary development of its black and remarkably elongated, stiff, black perithecial tip; which is bent to one side in such a fashion that the body of the perithecium and the receptacle are turned edgewise in preparations under a cover glass, and the arrangement of cells $f$ to $g$ is thus not determinable in fully developed individuals after they are mounted. Four mature and several younger individuals have been examined. 


\section{Chitonomyces inflatus nov. sp.}

Form rather stout; hyaline, becoming very faintly yellowish. Basal cell suffused with blackish brown, deeper below, conspicuously inflated above; cell $b$ small, somewhat broader than long, but forming an abrupt constriction between cell $a$ and the cells above, usually slightly distorted from the fact that the receptacle is often more or less geniculate in this region; cell $b$ followed by two relatively large cells, apparently cells $d$ and $e$, which are subequal, broader, and distinguished by a slight indentation above; a third cell, apparently cell $c$, small, subtriangular, lying somewhat obliquely above them is visible only on the left side; cell $f$ relatively short, ending in the insertion of the secondary appendage, the appendiculate cell $h$ not being separated from it; cell $h$ overlapping cell $f$ for about half its total length; cell $i$ normally longer than broad, tapering slightly to its nearly symmetrical rounded tip. Perithecium relatively large and stout, curved outward distally, its upper half free; the tip slightly distinguished and bent outward; the apex hardly distinguished, rather narrow, blunt, subsymmetrical; one or more of the lip-cells slightly prominent. Spores about $40 \times 2.5 \mu$. Perithecium $75 \times 25 \mu$. Total length to tip of perithecium 100-120 × 26-30 $\mu$.

On the anterior legs of a small dark dityscid. Manila, P. I. (Banks), No. 2409.

A species readily distinguished by its large inflated and suffused basal, and its constricted subbasal cells. It corresponds to C. Bidessarius and a few species among those which inhabit hosts other than Laccophili, from the fact that no appendiculate cell $h$ is separated from cell $f$. The identity of cells $c$ and $d$ is also obscure, it being uncertain whether the small cell mentioned in the description, which lies above and partly overlaps the other two, should be regarded as cell $c$ or cell $d$.

\section{Chitonomyces excavatus nov. sp.}

Wholly hyaline. Basal cell rather short and stout, not twice as long as broad: cell $b$ flattened, horizontal; cells $d$ and $e$ similar, greatly elongated, becoming slightly broader distally; cell $e$ slightly longer, cell $d$ surmounted by cell $c$, which is relatively small and subtriangular; cell $h$ not separated from cell $f$, which thus tapers to its appendiculate point, and is about half overlapped by cell $g$, its whole length being about equal to that of cell $e$; cell $g$ rather strongly convex externally 
toward its distal end, rather large; cell $i$ normal, slightly longer than broad, subsymmetrical. Perithecium relatively short, about one fourth free; the tip curved abruptly over a rounded concavity formed by a large, broad, blunt, erect, tooth-like external process: the small somewhat compressed apex subtended on the inner side by a flattened elevation resulting from a thickening of the wall. Spores about $45 \times 2.5 \mu$. Perithecia about $70 \times 20 \mu$, exclusive of the tooth-like process which is $11 \times 18 \times 22 \mu$. Total length to tip of perithecium $12-150 \times 30-35 \mu$.

On the margin of the right elytron of a small dark dityscid, Manila, P. I. (Banks), No. 2409.

This species, like the preceding which occurs on the same host, lacks the usually secondary appendiculate cell, which is not separated from the end of cell $f$. It is well distinguished by the abrupt concavity formed between the tip of the perithecium and the prominence which subtends it externally. It is further peculiar from the unusual development of cells $d$ and $e$ which are relatively much more elongate than in any other described species.

\section{RICKIA.}

Owing to the considerable variety and diversity of the hosts attacked by species of this genus it promises to become one of the largest among the Laboulbeniales. I have referred in a previous paper, (These Proceedings, 47, 10, 1912), to the diversity presented by the different forms which have thus far come under my observation, and to their considerable variations from the type form as it is illustrated by $R$. Wasmanni of Europe. A study of very copious material has led me to believe, however, that in this as in other groups of which our knowledge is still fragmentary, it is far better to interpret generic types with great liberality. I have, therefore, preferred to make the genus Rickia a rather comprehensive one, the variations as to antheridia, character of the axis, whether branched or simple, triseriate or biseriate, which are the more important matters in which divergence is observable, being so combined or transitional that a subdivision has seemed to me distinctly undesirable.

As in the paper cited above, I have called the appendage which always terminates the axis of young individuals and which, together with its two-celled base, may be carried up by the developing receptacle or left near the base as a lateral appendage, the primary appendage. 
In triseriate forms the middle series is called median, the lateral series on the perithecial side anterior, while the other is called posterior. It should be mentioned also, that the cell-numbers in the different cellseries may vary, even in the so-called "determinate" receptacles; being often less numerous in small and depauperate individuals or more numerous in those which are more luxuriantly developed, although the average number is usually uniform.

\section{Rickia Passalina nov. sp.}

Wholly hyaline. Axis indeterminate, slender, elongate, simple or once to several times variably branched; the cells of the receptacle biseriate above the single basal cell, mostly several times longer than broad, shorter and somewhat broader immediately below the perithecium; the cells of both rows, more often every second cell, cutting off a small appendiculate cell distally and externally, which is separated from the appendage by the usual, though not very conspicuous, blackish septum; the appendages four or five times as long as broad, for the most part appressed or but slightly divergent, those near the perithecia usually somewhat stouter and longer: the slightly tapering base of the primary appendage projecting distally and externally from the second cell of the anterior series, and consisting of a large basal and much smaller distal cell which is separated from the short appendage by a blackened constricted septum. Perithecia terminating the primary and secondary axes, rather long and narrow; the anterior margin free nearly to the base; the posterior united throughout to the last five cells of the posterior cell-series of the receptacle, all of which are without appendages, with the exception of the last, which bears one terminally just below the free apex of the perithecium, the body of which is slightly and subsymmetrically inflated; the tip externally or laterally geniculate, being bent abruptly sidewise or inward; the apex slightly recurved, tongue like, subtended by a prominent elevation. Spores about $20 \times 2.5 \mu$. Perithecia $40 \times 10 \mu$. Total length of axis varying from about 150 to $900 \mu$, its width 8-12 $\mu$. Appendages 9-12 $\times 2.5 \mu$.

On Passalus cornutus Fabr. (Type), M. C. Z., No. 2172, Ganard Co., Kentucky (Hyatt). On passaline beetles of various genera and species from: Para and Manaos, Brazil, Nos. 2215 and 2235, 2223, M. C. Z. (Mann); Grande Etang, Grenada, B. W. I., No. 2069; Dominica (Laudet), No. 2170, M. C. Z.; No 2169, M. C. Z., Polvon, Nicaragua; No. 2163, and 2161, Guatemala, both in M. C. Z. 
This species appears to be very common and widely distributed. It belongs to the type formerly distinguished as 'Distichomyces' the very slender receptacle being biseriate instead of triseriate as in a majority of the Rickiae. The antheridia are scanty and the antheridial cells appear to become free in rather irregular groups. The axis though often simple may be divided into several more or less elongate secondary axes, or a main axis may persist from which as many as ten short secondary axes may arise on either side, and since each axis is eventually terminated by a perithecium there may sometimes, though rarely, be as many as a dozen of the latter on a single individual. The unbranched condition appears, however, to be the normal one, although, whenever the termination of an axis is injured, branching invariably follows. The peculiar contour seen in the side view of the tip of the perithecium is usually not visible owing to the fact that the latter is more often bent abruptly sidewise so that it is viewed end on in most preparations. Its outline is somewhat variable, the tongue-like projection being stouter or more slender in different cases and more or less distinctly recurved, while the subtending rounded projection which, together with the tongue, remotely suggests the head of a tufted fowl, is also variable in its prominence. The species is most nearly allied to $R$. nutans of Ceylon.

\section{Rickia apiculifera nov. sp.}

Axis typically simple, not infrequently rather copiously branched, especially when injured; sometimes rather broad and short, but often greatly elongated; not infrequently slightly broader just above the single basal cell, but sometimes quite slender throughout; all the axes finally terminating in perithecia; the axis biseriate, the cell-number indeterminate; usually not much longer, often shorter, than broad. The basal cells of the primary appendage arising, usually, from the third or fourth cell above the basal cell, on either the anterior or posterior side. The appendages in general rather large, usually more or less persistent, numerous, divergent, especially near the base, irregularly distributed. Antheridia scanty, the cells becoming free. The terminal cell of the anterior cell-series larger and broader, and distally in oblique contact with the base of the perithecium; or extending upward beside it, and sometimes cutting off a terminal appendiculate cell which may reach even to the middle of the anterior margin of the perithecium; the posterior series of axis-cells continuous 
along the corresponding margin of the perithecium, which is thus united on this side to a series of usually five or six cells, some or all of which may each cut off an appendiculate cell; the terminal one either bearing an appendage directly; or cutting off a large appendiculate cell distally, which lies just below the apex of the perithecium. Perithecium relatively long and narrow, its anterior margin one half to almost wholly free; the tip distinguished; the apex ending in a slightly bent, free, bluntly pointed projection formed by one of the inner lipcells. Spores 25-28 $\times 3-4 \mu$. Perithecia $36-50 \times 10-16 \mu$. Total length very variable, $100-1000 \times 10-20 \mu$. Appendages $18-20 \times$ $3.5 \mu$.

On Passalus tlascala Perch., (Type), No. 2068 and Neleides antillarum Arrow, No. 2069, Grand Etang, Grenada, B. W. I. On several passalline beetles; No. 2162, Guatemala, M. C. Z.; No. 2163 and 2165, Guatemala (Kellerman); No. 2166, Yucatan, M. C. Z.; No. 2167, Polvon, Nicaragua.

This species differs from all other known forms which possess a similarly pointed perithecium, in developing no axes which are indeterminate and sterile; every axis, whether primary or secondary, finally ending in a perithecium. It is extremely variable in habit; typically simple; but when growing luxuriantly, tending to branch copiously and to become greatly elongated.

\section{Rickia bifida nov. sp.}

Wholly hyaline. Receptacle consisting of a short basal stalkportion, including a larger basal cell and usually three smaller subequal cells, the upper two paired; the remainder of the main axis above this short stalk-portion and a branch near its base, though occasionally subject to abnormal branching, usually form two broad simple upcurved, subsymmetrical, slightly tapering, often nearly similar, elongate slender divisions with indeterminate apical growth; the cells of which are biseriate, mostly several times longer than broad, some, both of the inner and outer series, cutting off appendiculate cells; the appendages thus arising at irregular intervals, of the usual type, appressed or but slightly divergent, cylindrical or slightly tapering: the primary appendage small, borne on a large straight slightly inflated two-celled free base, arising from the second outer cell of the axis-division, the basal cell three times as long as the terminal. The perithecium arising at or near the base of the axis-division; mostly 
erect on a short stalk, which consists of a pair of cells; the anterior triangular, its upper angle extending above the base of the ascigerous cavity; while the posterior does not extend beyond this cavity, and forms the base of a series of four successively smaller flattened cells which lie in contact with the posterior margin of the perithecium; the series ending below the apex, the first and fourth cells appendiculate. Perithecia rather long and narrow, hardly inflated; the tip usually more or less clearly distinguished; the apex ending in a blunt, fingerlike, erect projection. Spores $28 \times 2.5 \mu$. Perithecia $35=40 \times$ $10 \mu$; the marginal cells $\times 3.5 \mu$; the stalk $9 \times 6-7 \mu$. Stalk portion of receptacle $7-12 \times 7-12 \mu$; its longest divisions $75-100 \times 5.5-7 \mu$. Free base of primary appendage $12-16 \times 3.5-4 \mu$. Appendages $15-20 \times 3 \mu$.

On various passaline beetles, No. 2163 (Type) and 2164, Guatemala (Kellerman). Nos. 2168 and 2169, Polvon, Nicaragua (M. C. Z.); No. 2171, Rio de Janeiro (M. C. Z.); No. 2238, Amazon (Mann), M. C. Z.

This small and delicate species is closely allied to the $R$. dichotoma and $R$. apiculifera. From the former it is distinguished by its small size, general habit, and by minor details of structure; while from forms of the latter which have produced irregular and abnornal branches, it is sometimes distinguished with difficulty. The divisions of the receptacle, however, do not produce perithecia terminally; and, in normally developed individuals a single perithecium, only, arises on a short stalk from near the base of one of the divisions.

\section{Rickia dichotoma nov. sp.}

Hyaline, branched, the axes biseriate. Basal cell of the receptacle broad, pointed distally, its upper half or more intruded between two irregularly paired cells lying above it, which it may almost completely separate; this pair is followed by two cells irregularly paired, above which the receptacle becomes furcate; one or both of its two stout divisions becoming once more, often almost immediately, furcate; one or both of the inner branches terminating in a perithecium; the others indeterminate, somewhat tapering, rather straight and rigid at least below, often greatly elongated; some of the cells bearing small appressed appendages which occur scattered on both sides; all the branches consisting of biseriate cells, and diverging more or less regularly at an angle of about $45^{\circ}$. The perithecial axes of variable length, 
the cells asymmetrically placed with reference to one another, four to twelve in each series; the upper cell of the anterior series protruding abruptly beside the base of the ascigerous cavity: the posterior series continued along the posterior margin of the perithecium nearly to its apex; these marginal cells, six to seven in number, successively smaller, externally hardly convex, all of them usually cutting off distally and laterally small appendiculate cells, except the basal and also the subterminal cell, which is smaller than the terminal; the latter being an appendiculate cell separated from it distally. Perithecia relatively long and narrow; the anterior margin and the apex free, the latter terminating in a well defined, erect, short, stout prolongation of one of the inner lip-cells; the tip well distinguished. Base of the primary appendage long and slender, arising externally from the third, fourth or fifth cell above the basal cell of the receptacle. Spores about $30 \times 3.5 \mu$. Perithecia $55-65 \times 14-18 \mu$, the marginal cells $\times 7 \mu$. Basal part of the receptacle $45 \times 30 \mu ; \times 12 \mu$ at base; its longest divisions $250-675 \mu$.

On the superior surface of a species of Euzercon parasitic on passaline beetles; No. 2794, Diquini, Hayti, M. C. Z. (Mann).

A species most nearly related to $R$. Cornuti, and also to $R$. arachnoides among other species parasitic on mites. From the latter it is at once distinguished by the straight hyaline projection from the apex of its perithecium.

\section{Rickia Cornuti nov. sp.}

Hyaline. Receptacle branching, the axes biseriate: consisting of a short basal primary axis comprising a small basal cell, the pointed end of which is usually intruded between the lower of usually two successive pairs of cells, all the members of which may cut off one or more, often two, appendiculate cells; the slender two-celled, straight, narrowly conical, free divergent base of the primary appendage arising from, or just above, one of the upper members. Above, the receptacle is divided into two somewhat divergent branches: one of them simple or giving rise from the inner side near the base to one, rarely two, short perithecial branches; always greatly elongated, with indeterminate apical growth, the very numerous cells biseriate and for the most part cutting off appendiculate cells bearing appendages of the usual type: the other division similar, or more often shorter, and terminated by a perithecium. Perithecia rarely nearly sessile, more often borne on a variably developed axis of biseriate cells irregularly paired, from two 
to eight in each series, one to four if borne on a special secondary perithecial branch; the upper cell of the anterior series extending only to the base of the ascigerous cavity; the posterior series continuous with a row of usually seven appendiculate, rather prominently convex, rounded, subequal cells in contact with the posterior margin of the perithecium nearly to its apex; the uppermost of these cells broader and rounded distally, unlike the others in bearing its appendage directly, without any basal cell, on its inner distal surface. Perithecium relatively long and narrow, its anterior margin wholly free; nearly straight or rather strongly convex; the tip well distinguished; the apex terminating in a well marked, erect, terminal, blunt, short projection formed by one of the inner lip-cells. Appendages very numerous, slightly tapering, rather stout, appressed or slightly divergent. Spores about $36 \times 4 \mu$. Perithecia $60-75 \times 14-18 \mu$, the marginal cells $\times 10 \mu$. Basal portion of the receptacle $18-27 \times 25 \mu$, the basal cell $\times 9 \mu$. Longest division of the receptacle $675 \mu$ (varying to less than half this length), its width $12 \mu$, becoming less distally. Appendages $16-18 \times 2.5-3.5 \mu$. Base of primary appendage $16-18$ $\times 4.5$ (base) $-1.8 \mu$ (apex).

On Passalus cornutus Fabr., No. 2172 (M. C. Z.), Ganard Co., Kentucky (Hyatt).

This species appears to be most nearly related to $R$. dichotoma from which, as well as from other nearly allied forms, it is at once distinguished by the presence of paired appendages on all the cells of the basal part of the receptacle, with the exception of the basal cell itself. The greatly elongated divisions of the receptacle are more or less flaccid, and tend to become spirally twisted in mounting, in contrast to the more or less rigid divisions of $R$. dichotoma. It is subject to considerable variation in size and in general habit, owing to the fact that one of the long divisions of the receptacle may be replaced by a much shorter division, terminated by a perithecium, and that one or two additional perithecia may arise on short secondary branches from either of the main divisions near the base. No antheridia have been recognized in the material examined.

\section{Rickia depauperata nov. sp.}

Minute, hyaline, usually short and stout, receptacle biseriate. Basal cell abruptly distinguished, short, stalk-like, sometimes more than half included between the basal cells of the anterior and poste- 
rior cell-series, which may extend obliquely downward nearly to the foot. Receptacle biseriate; the anterior series consisting of usually four subequal cells, and extending to or above the middle of the perithecium, all but the uppermost usually cutting off an appendiculate cell: posterior series consisting of seven or eight cells, mostly broader than long, their longer axes more or less radially arranged, cutting off distally and externally appendiculate cells which are somewhat prominent; the two celled base of the primary appendage diverging from the fifth or sixth cell, the subterminal cell not associated with an appendiculate cell; the terminal cell bearing an appendage directly, the blackened base of which lies close beside the apex of the perithecium. Perithecium straight, erect, half or less free along the anterior margin, tapering distally, the tip hardly distinguished, the apex ending in a blunt free prolongation of one of the inner lip-cells. Appendages short and stout, often considerably inflated, the free dark base often cup-shaped. Spores about $18 \times 2 \mu$. Perithecia $20-28 \times$ $7-9 \mu$. Total lengths to tip of perithecium $35-40 \times 19-23 \mu$. Larger appendages $7 \times 3.5 \mu$.

On Celaenopsis sp., collected in Hayti by W. H. Mann, M. C. Z., No. 2795 (type), Diquini; No. 2792, Petion; No. 2793, Cape Haytien.

A minute species allied to $R$. Euzerconalis, but at once distinguished by the absence of any median cell-series. No antheridia were recognized in the dozen or more individuals examined.

\section{Rickia Dominicensis nov. sp.}

Receptacle triseriate, the anterior series reduced to two cells; the posterior and the median, which originates near the middle of the perithecium, forming together a slender free flagellum: hyaline, except the basal cell; which is hyaline below, its distal portion prolonged upward on the posterior side and deep black, except at its tip, the opaque area extending obliquely up beside the two lower cells of the posterior series, forming a contrasting margin, its hyaline apex ending at or near the blackened base of the first posterior appendage: anterior series consisting of two cells; the lower subtriangular, its inner margin convex, cutting off distally and externally an appendiculate cell; the upper lying in somewhat oblique contact with the base of the perithecium, its attenuated distal portion curved up beside the lower fourth of the anterior margin of the latter: the four lower cells of the posterior series long, subequal; the fourth reaching nearly to 
the tip of the perithecium; the second united wholly, the third for half its length to the posterior margin of the perithecium; the lowest, which is broader below, separating by its whole width the lower cell of the anterior series from the basal cell of the receptacle: the posterior series, a majority of the cells of which cut off single appendiculate cells distally and externally, becomes united above the middle of its third cell to the cells of the median series; which are long and flattened, without appendages, the two lower united to the upper half of the inner margin of the perithecium nearly to its apex; the posterior and median series together forming a long, slender, tapering, free, flagellum-like prolongation; which is determinate, owing to intercalary division below the two-celled base of the primary appendage, by which it is terminated; the cells of the two series irregularly paired. Perithecia erect, long and narrow, the tip somewhat distinguished, slightly bent distally, the apex terminating in a slightly curved projection. Spores about $20 \times 2 \mu$. Perithecia about $36 \times 6 \mu$. Opaque portion of basal cell $26 \times 3.5 \mu$. Total length to tip of perithecium about $50 \mu$; to tip of flagellum (variable) $160-190 \mu$. Greatest width $15 \mu$. Appendages $15-25 \times 3 \mu$.

On antennae of a large species of Passalus?; Dominica, B. W. I., No. 2170, M. C. Z.

This peculiar and aberrant species is at once distinguished by the blackened extension of the basal cell which closely resembles in general appearance the similar modifications of the basal cells which occur in many of the stilicolous species of Corethromyces. It is most nearly related to the African $R$. filifera, in which the median series of cells, which in the present species form the inner half of the flagellum, is replaced by two cells lying opposite the apex of the perithecium; the free portion of the flagellum being therefore uniseriate. A reëxamination of abundant material of the African form shows, also, that the flagellum, as in the present species, is terminated by the primary appendage and its two basal cells.

\section{Rickia parvula nov. sp.}

Hyaline. Basal cell short, irregularly triangular; its base, only, free; obliquely and asymmetrically adjusted to the two cells above it. Receptacle triseriate, the anterior series consisting of four superposed cells, the two lower greatly flattened and obliquely associated, the lower cutting off a relatively large appendiculate cell distally and 
externally; the third small and subtriangular, extending inward below the base of the ascigerous cavity; the fourth flattened beside the outer margin of the perithecium, extending upward perhaps one third of its length, and so narrow as to be hardly recognizable: median series consisting of seven obliquely superposed cells; the two lower smaller, the lowest somewhat above the base of the perithecium, the upper four externally free, the uppermost bearing a terminal appendage directly; the two lower cutting off appendiculate cells, while the subterminal is without any appendage: posterior series consisting of three or four cells, each cutting off an appendiculate cell distally and externally, the upper larger, the uppermost also bearing the large base of the primary appendage which diverges slightly from it laterally and distally. Perithecia relatively large, somewhat curved inward throughout; the tip rather short and moderately distinguished; the apex broad, blunt, bent slightly sidewise. Spores about $16 \times 2 \mu$. Perithecia $28 \times 9 \mu$. Total length to tip of perithecium $40 \times 18 \mu$. Base of primary appendage $10 \times 3.5 \mu$.

On Celaenopsis sp., No. 2697, St. Anns Valley, Port of Spain, Trinidad.

This minute form was found in company with $R$. excavata. It is distinguished from depauperate forms of $R$. Euzerconalis by the blunt apex of its perithecium, which lacks the finger-like projection so characteristic of this and numerous other species. Two mature specimens, only, have been examined, in which no antheridia were recognized.

\section{Rickia radiata nov. sp.}

Hyaline, triseriate. General form short and compact with more or less even outline, basal cell forming a well developed abruptly differentiated stalk, the apex of which is intruded between, and nearly separates, the paired triangular basal cells of the anterior and posterior series, one or both of which may cut off marginal appendiculate cells distally and externally; one or both of the basal cells themselves grow downward to form an elongated, attenuated, hyaline, buffer-appendage which may or may not be separated by a septum at the base. Receptacle triseriate, subdeterminate; the anterior series consisting of five cells, the second and third broader; each cutting off distally and externally one, sometimes two, superposed small cells which bear prominently projecting subulate hyaline sessile antheridia, which are not distinguished by any blackened septum; the fourth cutting off an 
appendiculate cell; the fifth smaller and bearing the long straight narrow free, somewhat divergent base of the primary appendage, which consists of two nearly equal cells: the middle series consisting of four, or usually five, subequal cells, extending in contact with the inner margin of the perithecium to the point where the base of its conical free tip is faintly distinguished: the posterior series consisting of three or four cells, the second cutting off one or two superposed small cells bearing subulate antheridia; the third, or third and fourth, extending up along the anterior margin of the perithecium to about its middle. The antheridia and appendages more or less radiately disposed; the latter all, with the exception of the primary, relatively long, especially those from the basal cells, and all distinguished by a relatively long constricted blackened base. Perithecia rather short and stout, distally subconical; the tip hardly distinguished; the apex broad, truncate, or bluntly rounded. Spore $22 \times 2.5 \mu$. Perithecia $28 \times 11 \mu$. Antheridia 6-7 $\mu$. Longest appendages $24 \times 3.4 \mu$; base of primary appendage $10-12 \times 3 \mu$. Outgrowths from basal cells $30-55 \mu$. Basal cell of receptacle $10-15 \times 5.5 \mu$. Total length to tip of perithecium $45-55 \times 23-28 \mu$.

On Celaenopsis sp., No. 2780, Kamerun.

A species most nearly allied to $R$. Celaenopsis, distinguished by the subradiate arrangement of its antheridia and appendages, the sessile subulate character of the former, and the long blackened bases by which the latter are distinguished. The attenuated buffer-outgrowths from the basal cells of the two outer series, though not always present, are not known in any other species of the genus.

Rickia Hypoaspitis nov. sp.

Receptacle hyaline triseriate. Basal cell relatively large, not intruded distally. Receptacle triseriate; the anterior series consisting of two, rarely three, superposed cells; the lower somewhat larger, usually, but not always, cutting off an appendiculate cell distally and externally; the uppermost cutting off a similar cell which bears a sessile pointed compound antheridium, the neck of which bends upward beside the base of the perithecium: the posterior series consisting of four or five cells, one to several of which cut off appendiculate cells distally and externally; the uppermost bearing the base of the primary appendage which projects free, and is strongly divergent, rather stout, its two cells nearly equal: the middle series consisting 
of three, very rarely of four, usually subequal flattened cells, all of which are in contact with the inner margin of the perithecium to its tip; the uppermost extending above the corresponding cell of the posterior series. Perithecium rather short and stout, its anterior margin almost wholly free, the tip not distinguished, its apex bluntly rounded. Spores about $18 \times 2.5 \mu$. Perithecia $35 \times 12 \mu$ the marginal cells $\times 3 \mu$. Appendages $10-12 \times 3.4 \mu$. Basal cell $10-12 \times$ 4.5-5 $\mu$. Total length to tip of perithecium 55-65 $\times 16-25 \mu$.

On Hypoaspis sp., No. 2797, Grand Etang, Grenada, B. W. I.

This very minute species is perhaps most nearly related to $R$. Celaenopsis. As in this species, its sessile antheridium arises at the base of the perithecium and is not distinguished by any blackened base, a characteristic also found in $R$. minuta. The host is a very minute mite which was found parasitic on a termite, and which Mr. Banks, who has kindly examined it for me, regards as a new species.

\section{Rickia Euxesti nov. sp.}

Hyaline, short and usually stout. Receptacle triseriate, the basal cell forming a short stalk, usually bent slightly, and distally intruded between the subsimilar basal cells of the two marginal series: the anterior series consisting of five, rarely six or four, superposed cells, broader than long, their transverse axes often subradiately arranged, the upper slightly larger, the uppermost lying below the base of the perithecium which is slightly tipped to one side; all the cells, except the one or two lowest, cutting off one, often two relatively large cells distally and externally, a majority of which usually bear typical antheridia, while a few may be appendiculate: median series consisting of four, rarely five or three cells, the two, rarely three, lower usually larger, subequal, lying below the base of the perithecium; the two, rarely three, upper successively smaller and flatter, lying in contact with its inner margin: posterior series consisting of seven to rarely nine or five cells, the upper three or four successively much smaller, the rest subequal, the uppermost bearing the basal cell of the primary appendages, the rest, except the lowest, cutting off one, or less often two, relatively large superposed cells which bear either appendages or antheridia: all the cells of the receptacle proper lying below the perithecium of about the same size, the latter subtended by a distinct stalk-cell. Antheridia relatively large and numerous, the basal ring broad, the neck strongly curved outward. Appendages scanty, 
usually broken and proliferous, rather short, subcyclindrical. Perithecium slightly tilted inward, its body subsymmetrical, long elliptical, the outer margin free, the broad short tip slightly distinguished, the apex broad, blunt, symmetrically rounded. Spores about $18-20 \times 2.5 \mu$. Perithecia $26-36 \times 16-18 \mu$. Antheridia $10 \times 3.5 \mu$. Total length to tip of perithecium 50-90 $\times 20-26 \mu$, smaller specimens $30 \times 15 \mu$.

On Euxestus Parki Woll., Nos. 2419, 2422 and 2552, Manila, Philippines.

A species somewhat similar to $R$. Europsis, but clearly distinguished by its large curved antheridia and nearly free perithecium, as well as by other points of difference. On the smaller hosts it is less well developed, smaller, less stout, with fewer cells.

\section{Rickia Europsis nov. sp.}

Hyaline, short and stout, broadly elliptical but asymmetrical, the posterior margin being more or less straight. Basal cell small, short, abruptly distinguished from the body, its pointed distal end symmetrically intruded between the nearly equal and similar basal cells of the two marginal series. Receptacle triseriate: the anterior series more distinctly and evenly convex; consisting of nine, less frequently ten cells, broader than long except the distal ones, abruptly successively larger, or the three lower larger; each, except the terminal, and sometimes the subterminal, separating a cell distally and externally, sometimes two, which bear antheridia or appendages of the usual type: posterior series consisting of six or seven cells, the lower four or five large, subequal, forming a straight erect series; all broader than long and separating distally and externally one, or often two, small cells which bear antheridia or appendages; the series ending in the two relatively short and broad cells which form the base of the primary appendage: the median series consisting of normally seven successively smaller cells in contact with the posterior margin of the perithecium, and extending from just below its base somewhat beyond the base of the primary appendage to its tip. Appendages rather short and stout. Antheridia typical, short and stout, the neck rather broad and not very abruptly distinguished. Body of the perithecium symmetrical, long-elliptical, hardly more than its apex free; the latter blunt and bent abruptly sidewise. Spores about $24 \times 3 \mu$. Perithecia $40-54 \times 16-18 \mu$. Appendages $6-9 \times 4 \mu$. 
Antheridia $7 \times 3.5 \mu$. Total length to tip of perithecium $60-66 \times$ 36-43 $\mu$.

On Europs sp., No. 2338, Kamerun, W. Africa.

In general appearance this species bears some resemblance to $R$. elliptica, from which it is readily distinguished by its numerous typical antheridia, and the absence of any terminal projection from the tip of the perithecium.

\section{Rickia gracilis nov. sp.}

Hyaline, elongate, of nearly the same width throughout. Receptacle triseriate, the basal cell usually abruptly bent, brown next the foot but otherwise hyaline, intruded so as to separate completely the basal cells of the marginal series: anterior series consisting of about twenty cells very obliquely related and several times longer than broad; the uppermost, only, lying beside the base of the perithecium; all, including the lowest, cutting off two, to less often four, cells, which bear appendages or antheridia: posterior series similar to the anterior, and consisting of about twenty cells which extend hardly higher than those of the anterior series, and bear terminally the rather long slender base of the primary appendage: median series consisting of about eighteen cells of regular form and diameter, from four to six times as long as broad, except the uppermost; the three to four distal ones successively smaller and rounded, the last three lying beside the lower fourth of the perithecium. Antheridia numerous, hyaline, the venter rather stout, the neck slightly curved and moderately well distinguished. Appendages normal, slender, relatively long, hardly tapering. Perithecia yellowish with a tinge of purplish, erect symmetrical, except the base, which turns outward slightly, three fourths free, or slightly more, externally; the margins slightly convex, tapering symmetrically to the small truncate apex; the tip somewhat paler, and not distinguished. Spores about $35 \times 3.6 \mu$. Perithecia $75 \times 29 \mu$. Antheridia $14 \times 4 \mu$. Appendages $10-20 \times 3 \mu$. Total length to tip of perithecium $450 \times 34 \mu$; the receptacle for the most part $\times 26 \mu$.

On Stenotarsus Guineensis Gerst., No. 2363b, Kamerun.

A well defined species, quite unlike the others occurring on the same host; and distinguished by its long, slender, uniform receptacle, and laterally placed, erect, symmetrical perithecium. Six specimens have been examined, only one of which is fully matured. 


\section{Rickia Danaëalis nov. sp.}

Hyaline; form sometimes short-triangular below the free distal half of the perithecium. Receptacle triseriate; the basal cell relatively large and broad, somewhat intruded between the two marginal cells above it, or more often adjusted to the basal cell of the anterior series; that of the posterior tapering to a narrow contact base: anterior series consisting of usually seven or eight cells, somewhat irregular in outline, the three or four distal ones smaller, lying beside the lower third or more of the perithecium; all, except the lowest, cutting off one cell or two cells irregularly superposed or lying side by side, which bear, the lower ones usually antheridia, the upper usually appendages: posterior series similar to the anterior, consisting of usually five or six cells; the lowest larger than the corresponding cell of the anterior series, the cells of both series above them asymmetrically disposed; the series terminated by the free, or almost wholly free, stout, divergent base of the primary appendage: median series consisting of five or six cells, often as large as those of the posterior series; the four or five upper, and sometimes part of the lowest, lying beside the perithecium; the uppermost distally free between the perithecium and the base of the primary appendage; the basal one intruded somewhat between the second cells of the two marginal series, or between the second posterior and the third anterior marginal cells. Appendages relatively long and divergent; hyaline, becoming tinged with brown, especially at the base; straight, nearly cylindrical, tending to form two distal symmetrically divergent tufts; the primary appendage longer, more deeply suffused. Antheridia of the normal type; hyaline, slightly curved; the necks rather short and well distinguished, usually in pairs, arising from the second and third, sometimes also the fourth, cells of the anterior series. Perithecium subtended by a well marked stalk-cell, somewhat lateral, two thirds to more than one half free on both sides, thick-walled, nearly straight, or more or less distinctly bent distally; the middle third of the free portion slightly convex along the posterior margin; the tip otherwise hardly differentiated, somewhat asymmetrically conical, tapering to a blunt point. Spores about $36 \times 3.6 \mu$. Perithecia about $75-95 \times 28-32 \mu$. Antheridia $16 \times$ $5.5 \mu$. Appendages, lower $20 \mu$ the upper to $65 \mu \times 7 \mu$. Primary appendage to $75 \mu$, its base about $18 \times 10 \mu$. Total length to tip of perithecium $120-190 \times 45-60 \mu$.

On various parts of Danaë Senegalensis Gerst., No. 2570, Kamerun. 
A clearly defined species which varies somewhat in its general form according as it is shorter, stouter and broadly triangular, or more elongate. The long, stout, basally suffused, more or less symmetrically divergent distal groups of appendages give it a characteristic appearance.

\section{Rickia Scydmaeni nov. sp.}

Receptacle triseriate, straight, or bent just above the basal cell, hyaline, subsymmetrical in outline; broad distally, and tapering continuously and considerably to the sometimes rather abruptly distinguished long basal cell, the round extremity of which is slightly intruded between the two lower cells of the marginal series; which are somewhat longer and unequal, and very obliquely separated from the two cells next above: anterior series consisting of six or usually seven cells; shorter, smaller and more rounded distally; all except the lowest usually cutting off a relatively large cell, which bears an appendage, or rarely an antheridium: posterior series similar to the anterior, consisting of usually seven cells: median series consisting of five successively smaller cells, the lowest lying above the second pair of marginal cells between which it is intruded; all three series extending upward to about the same level above the base of the perithecium, the cells rather irregular in form and size. Base of the primary appendage free, symmetrically adjusted to the two distal cells of the posterior and median series; its basal cell large and broad, the distal partly hyaline, or becoming nearly opaque and indistinguishable from the blackened constricted region which subtends the short inflated hyaline appendage; secondary appendages divergent, asymmetrically clavate, the basal blackish brown suffusion involving the lower half nearly or quite to the tip, the upper margin hyaline, at least distally. Antheridia normal, scanty, large, stout, with short not abruptly differentiated necks, as large, or nearly as large, as the appendages, similarly and evenly suffused. Perithecium about four fifths free, thick-walled, deeply suffused, but slightly asymmetrical, distally subconical; the large tip rather clearly distinguished, slightly inflated and darker in the middle, whence it tapers evenly to the small hyaline truncate apex. Base subtended by a well defined stalk-cell. Spores about $30 \times 3 \mu$. Perithecia $18 \times 4 \mu$. Appendages $18-22 \times 5.5 \mu$. Antheridia $18 \times$ $4 \mu$. Total length to tip of perithecium 150-160 $\times 35-38 \mu$.

On the inferior surface of Scydmaenus bicolor, No. 1422, Kittery Point, Maine. 
This species does not appear to be nearly allied to any described form, and is clearly distinguished especially by its dark appendages. It seems to be decidedly rare.

\section{Rickia Stenotarsi nov. sp.}

Quite hyaline, or the perithecium tinged with blue; tapering more or less symmetrically to the base, and often slightly twisted below, so that it is turned partly edgewise. Receptacle triseriate, the basal cell usually strongly bent, with a small brown patch next the foot, intruded between the two nearly equal cells above it, so as to separate them more or less completely; the anterior series extending to slightly below the middle of the perithecium; consisting of usually twelve somewhat elongated and flattened cells, the three upper smaller, lying beside the perithecium; all except the basal cell cutting off from one to three cells obliquely superposed, or lying side by side, or somewhat irregularly associated: posterior series similar to the anterior, consisting of usually eleven cells, the distal much smaller, round, and lying lower than the corresponding cell of the median series; the long, slightly tapering free base of the primary appendage diverging laterally between them: median series consisting of eleven or twelve cells, the three or four distal ones lying beside the basal third or less of the perithecium; the basal cell but slightly intruded between the second pair of marginal cells; the lower four or five cells subrectangular, twice or somewhat more than twice as long as broad. Antheridia hyaline, divergent, numerous, rather slender, often slightly curved; the neck not abruptly distinguished. Appendages hyaline, rather slender, slightly tapering, the lower shorter, the upper, including the primary appendage, much longer. Perithecium hyaline, or yellowish, or blue; the blue color, when present, extending to the well defined subtending stalk-cell or even lower; its posterior margin more than half free; nearly erect, relatively long, distally asymmetrical owing to a more or less distinct bend of the large long well distinguished tip, which is more convex on its inner side; the small narrow truncate or rounded apex turning more or less abruptly upward. Spores about $40 \times 4 \mu$. Perithecia $80-120 \times 28-35 \mu$. Antheridia $22 \times 4 \mu$. Appendages $22 \times 46 \times 4 \mu$. Total length to tip of perithecium $200-350 \times 40-55 \mu$.

On the elytra of Stenotarsus Guineensis Gerst., No. 2363, Kamerun, W. Africa. 
This well defined species is perfectly hyaline, except that in a majority of the very numerous individuals examined, the perithecia, and sometimes certain cells below it, are tinged with rather bright blue, as if stained with haematoxylin. That this color is not accidental seems to be indicated by the fact that some perithecia from the same source are quite hyaline, and that no other parts of any individuals are thus colored: yet it is not certain that this very unusual color may not have been due to the accidental presence of some staining material in the containing bottle.

\section{Rickia latior nov. sp.}

Quite hyaline, short and broad. Receptacle triseriate, the basal cell brown, its broad blunt upper half hyaline and completely separating the first pair of marginal cells: anterior series reaching to about the middle of the perithecium, consisting of ten obliquely superposed cells, all of which, except the basal, cut off from one to four cells, unusually prominent with free ends; which bear appendages, or copious antheridia, arising side by side in a more or less regular transverse series: posterior series consisting of eight cells, similar to the anterior, and terminating in a very small cell; which bears the large, long, slightly tapering base of the primary appendage: median series consisting of from six to eight cells; the lower three or four obliquely superposed; the upper three or four lying beside the lower two fifths or less of the perithecium, the uppermost opposite the last cell of the posterior series. Antheridia very numerous, long, slender, tapering, slightly curved, hyaline. Appendages variable in length, the uppermost usually longer; hyaline, tapering. Perithecia very thick-walled, becoming pale straw-yellow, asymmetrical, more or less strongly and abruptly curved inward, so that the apex may project laterally beyond the posterior margin of the receptacle; the tip very abruptly distinguished, especially along its anterior margin; the apex well distinguished, longer than broad, distally truncate, or obliquely rounded. Spores $38 \times 3.8 \mu$. Perithecia $80-90 \times 27-30 \mu$. Antheridia $9 \times$ $3.6 \mu$. Appendages $18-60 \times 3.6 \mu$. Total length to tip of perithecium $48-70 \mu$.

On the elytra of Stenotarsus Guineensis Gerst., No. 2363, Kamerun.

This form is perhaps too closely allied to R. Stenotarsi which occurs on the elytra of the same host. It differs in its short broad habit, obliquely superposed axial cells, simpler structure, more numerous 
antheridia, which often occur in fours; and the abrupt and peculiar distal modification of its perithecium; which is, however, faintly suggested by the bent tip of $R$. Stenotarsi. Were it not that the material of both is abundant and in perfect condition, and the individuals clearly distinguished in all cases, I should hesitate to separate them, and in any case it may eventually prove more desirable to separate the present form as a var. latior of the preceding.

Rickia introversa nov. sp.

Straight, short and stout, asymmetrical. Receptacle triseriate, the cell-numbers somewhat variable; the foot and basal cell large, the latter more or less completely and deeply involved by a brownish black suffusion; its apex slightly intruded between the cells above it: anterior series consisting of about sixteen cells and extending to the tip of the perithecium, which is bent abruptly over its broad, blunt termination; the subterminal cell and the one next below, extending higher than the small terminal one, which lies against the concave side of the perithecial tip; all the cells, except four or five of the flattened terminal ones, and usually also the basal, being sharply pointed outward; owing to the separation, distally, of a narrow cell, sharply pointed inward, which, in the lower members, may be nearly as broad as the cells from which they are separated, and which bear externally antheridia or appendages: posterior series similar in general to the anterior, consisting of six or seven stouter cells and ending in the lower of the two cells which form the base of the primary appendage; all, usually including the lowest, bearing antheridia or appendages laterally, not marginally, as in the anterior series; so that, when they lie at the right, their origins are not visible: median series consisting of four or usually five cells, its much larger basal cell not at all or but slightly intruded below. Appendages closely appressed, distally hyaline, and not clearly distinguishable, except their contrasting blackish brown bases, the suffusion extending some distance above the indistinguishable basal septum, and also involving more or less distinctly the cell which bears them. Primary appendage of the normal type, unlike the secondary; its base not clearly differentiated from the cells below it. Antheridia very large, scanty, appressed, or overlapping the receptacle; the necks long and stout, not abruptly distinguished. Anterior margin of the perithecium hyaline, united to the receptacle as far as the tip, which is bent abruptly over the rounded 
termination of the anterior series; its posterior margin about two thirds free above the base of the primary appendage: the apex blunt and more or less evidently and coarsely bilobed, the lobes lying side by side; a minute stalk-cell below the base. Spores scanty, about $18 \times 2 \mu$. Perithecia $35-40 \times 11-13 \mu$. Appendages $6 \times 1.5 \mu$. Antheridia $12 \times 2 \mu$.

On the upper surface of the abdomen of Coproporus latus Motsch., No. 2380, Mindanao, P. I.

This species is closely allied to the two following forms which occur on the same host, all of which have an appearance, unusual in members of this genus, from the contrasting suffusions of the bases of the appendages and of the cells which bear them, giving the margins a transversely banded appearance. There are not more than one or two antheridia distinguishable in any of the eight individuals examined, and the hyaline portion of the appendages is inconspicuous from its appressed habit, and tendency to become disorganized.

\section{Rickia nigrofimbriata nov. sp.}

Asymmetrical, straight. Receptacle triseriate, the basal cell relatively large, short, broad, subtriangular, becoming wholly suffused with brown: anterior series consisting of about sixteen cells which are subequal, except the five terminal ones which bear no appendages; the four subterminal more flattened, and obliquely superposed; the terminal forming a short, stout, rounded, free, finger-like prominence extending above the apex of the perithecium; the remaining cells, except the basal, cutting off a relatively large cell distally and externally; all of which, like the lower half of the small, stout, abruptly upcurved appendages, are nearly or quite opaque, giving the otherwise hyaline body a fringed appearance: posterior series similar to the anterior, consisting of eleven or twelve cells, the basal and distal without appendages: median series consisting of eight or nine successively smaller cells; the lowest slightly intruded between the third pair of marginal cells; the free base of the primary appendage placed between the two terminal cells of the posterior and median series, its basal cell short and broad, its distal nearly twice as long, and narrower; the appendage short, erect, normal. Perithecium relatively long and narrow; its posterior margin somewhat more than one half free, symmetrically somewhat convex; the tip not clearly distinguished, partly free above the anterior series; the apex bluntly 
rounded, bent sidewise; a small stalk-cell clearly distinguished. Perithecium $38 \times 10 \mu$. Appendages $6 \times 2.5 \mu$. Total length $80 \times 24 \mu$.

On the tip of the abdomen of Coproporus latus Motsch. No. 2381, Mindanao, P. I.

Three specimens of this species have been examined in which the spores are not fully matured in the asci. It is most nearly related to the two preceding species, especially to $R$. introversa, from which it is distinguished by the finger-like termination of its anterior cell-series, its differently shaped perithecium, more numerous cells, etc. More fully matured perithecia may show some further modification of the tip.

\section{Rickia inclusa nov. sp.}

Nearly symmetrical, except for the prominence of the distal cells of the anterior series; spathulate in habit. Receptacle subhyaline, except the lower appendiculate cells, triseriate, the basal cell short and stout: anterior series consisting of about twenty-five cells all, except the three terminal ones, cutting off distally and externally single triangular cells; the lower of which are flatter, broader and more sharply pointed inward, becoming deeply suffused, contrasting, and not differentiated from the bases of the appendages; the cell just below the base of the perithecium larger than the rest; the thirteen cells above it in contact with the perithecium, subequal, the two subterminal cells equal, flattened, obliquely tilted; the terminal one pointed inward distally and externally, forming a rounded free prominence: posterior series resembling the anterior in general, consisting of twenty subequal and subtriangular cells, the last cell cutting off a relatively large basal cell which, together with its appendage, is bent inward against the base of the primary appendage, the lowest cell of which is rounded and somewhat larger than the uppermost cell of the median series which it terminates: median series consisting of twenty cells, the six lying below the perithecium larger, irregularly rounded and subequal, the rest in contact with the perithecium, much smaller, rounded and subequal. Appendages small and appressed, blackish brown externally, bent upward at the more deeply suffused base; the cells which bear them, from below up to the base of the perithecium on the anterior side and to its middle on the posterior, also opaque and contrasting. Perithecia a little anterior in position, straight, erect, nearly symmetrical, fusoid-elliptical, broadest in the middle, completely enclosed by the receptacle, except the partly free short 
broad, erect tip; the apex bilobed, the large lobes unequal, somewhat asymmetrically and laterally placed; a minute subtending stalk-cell distinguished. Spores copious, about $28 \times 2.5 \mu$. Perithecium $77 \times 27 \mu$. Total length to tip of perithecium about $140 \times 50 \mu$.

On legs of Coproporus latus Motsch, No. 2380, Mindanao, P. I.

This species is most nearly related to the two species occurring on the same host ( $R$. introversa and $R$. nigrofimbriata), but is at once distinguished by its almost wholly included perithecium, as well as by other differences. Two specimens, only, one of them fully mature, have been examined. No antheridia are recognizable in either individual.

Rickia circumdata nov. sp.

Long-spathulate, nearly symmetrical, quite hyaline or more or less deeply and completely suffused with blackish brown, darkest at the base, and hyaline above; sometimes opaque below, and becoming gradually hyaline distally. Receptacle triseriate, subdeterminate, (in one instance biseriate), the basal cell always quite hyaline, contrasting: anterior series consisting of from about twenty to twenty-five cells, the lowest and uppermost smaller, the rest subequal when suffused, and much flattened, with straight walls, but tending to be piriform when hyaline; each cell cutting off two to three flattened triangular superposed cells, or the lower only one such cell, all of which bear appendages or antheridia: posterior series similar to the anterior and symmetrical with it, ending in the small lower cell of the base of the primary appendage, from which the free small upper narrow cell projects outward, parallel to the other appendages: median series consisting of about the same number of cells, which decrease in size from the mid-region upward and downward; those below the perithecium squarish or subrectangular; suffused, or more rounded in hyaline individuals; those in contact with the perithecium becoming much smaller upward; the lowest cell hardly intruded between the second pair of marginal cells. Perithecium slightly lateral in position, erect or slightly tilted, subfusiform, subsymmetrical, broadest just below the middle; becoming deeply suffused with brown, except in hyaline individuals; the tip distally compressed, not distinguished, usually turned sidewise so as to be free, the anterior and posterior series sometimes almost or quite meeting behind it; distally hyaline, compressed; the bluntly rounded or truncate apex always quite free. Appendages hyaline, subcylindrical, of the ordinary type, slightly 
longer than the numerous hyaline antheridia. The latter tapering, without abruptly defined necks. Spores about $28 \times 3 \mu$. Perithecia 54-64 $\times 20 \mu$. Appendages $12 \times 3 \mu$. Antheridia $10 \times 3.5 \mu$. Total length to tip of perithecium $130-175 \times 50-55 \mu$.

On Episcaphula piciventris Gorh. No. 2566, and Episcaphula spp. Nos. 2334, 2563 and 2566, Kamerun.

A species which in general form recalls $R$. inclusa, its perithecium being similarly surrounded by the receptacle. It varies from quite hyaline individuals to others which are more or less completely suffused and quite opaque below; the distal margin being, however, always hyaline. In one specimen examined the median series has failed to develop, producing an otherwise normal biseriate individual.

\section{Rickia Papuana nov. sp.}

Broadly spathulate, nearly symmetrical, tapering to a slender basal cell. Receptacle triseriate, hyaline: anterior series extending to the tip of the perithecium; consisting of twenty-five cells, more or less, all except the lowest much flattened; those beside the perithecium radiately arranged, and becoming gradually smaller distally; the lowest one or two cells cutting off one or two, the rest five or six small cells, which lie side by side horizontally, producing very numerous antheridia and scanty appendages: posterior row similar to the anterior and subsymmetrical with it; its basal cell much larger, consisting of about the same number of cells, ending in the base of the primary appendage, the two cells of which are separated by a very oblique septum, the lower thus greatly overlapping the upper on its inner side; its base broad, convex and included: median series consisting of about eleven cells, the lowest and those beside the perithecium smaller. Antheridia very numerous, hyaline, appressed; the necks well distinguished, purplish, the hyaline tips curved outward. Appendages hyaline, subcylindrical, appressed. Perithecium completely surrounded by the receptacle, a portion, only, of the tip free, subfusiform and subsymmetrical, the tip distally compressed and subcylindrical, partly free; the apex bluntly rounded. Perithecia about $75 \times 24 \mu$. Antheridia $12 \times 4 \mu$. Appendages $20 \times 4 \mu$. Total length to tip of perithecium $235 \times 90 \mu$.

On Catops sp., British New Guinea, No. 1840.

The hosts on which this peculiar form occurred were obtained for me in New Guinea by Mr. Muir to whose kindness I am much in- 
debted. Six individuals have been examined, in only one of which is the perithecium nearly mature, although no spores are visible. It is probable that the dimensions of the perithecium of more fully developed individuals will prove greater than those given above, and that its erect, free finger-like tip may become more prominent with age. The first appendiculate cell which is cut off, appears to bear an appendage; while all, or a great majority of those cut off beside it, which lie in a subhorizontal series, bear antheridia. Owing to the fact that the antheridia are thus crowded side by side, it is very difficult to estimate the number developed in connection with a given marginal cell, but there appear to be from four to six. The extremely oblique septation of the base of the primary appendage, is much more striking than in any of the several species where a slight obliquity is observable.

\section{Rickia pallida nov. sp.}

Hyaline, tapering symmetrically downward from the mid-region of the perithecium to the foot. Receptacle triseriate, the basal cell rather small, subtriangular, not distinguished from and slightly if at all intruded between the two cells above it: anterior series extending to, or almost to, the base of the perithecial tip, consisting of usually eighteen cells; the upper ten usually in contact with the perithecium, the distal ones smaller, those below the perithecium subequal, irregularly three-sided except the lowest; all the cells of the series, except the distal and basal, cutting off from one to five relatively small obliquely superposed cells bearing appendages or antheridia; the bases of which, crowded in oblique rows, are visible only on the left face, that is only when the anterior series lies at the left: posterior series consisting of about sixteen cells, similar to the anterior series, the basal cell also separating an appendiculate cell: median series consisting of more often fifteen cells, the four below the perithecium larger, irregularly squarish to hexagonal; those next the perithecium extending to the base of its tip, two or three of the distal ones extending beyond the base of the primary appendage, which is inonspicuous and projects somewhat obliquely from the left face; four or five successive distal cells of the series, usually not including the terminal one, cutting off one, or the lower two, appendiculate cells; the appendages, or their bases, lying on the right face. Antheridia numerous, hyaline, tapering almost uniformly to the blunt apex; the neck but slightly distinguished, straight or slightly curved. Appendages longer and larger 
than the antheridia, cylindrical or somewhat swollen, hyaline, becoming faintly yellowish. Perithecia almost symmetrically subfusiform, subtended by a well defined irregularly triangular stalk-cell, the tip wholly free or its base partly enclosed on one side, conical, its margins evenly continuous with those of the distal cells of the anterior and median series; the apex rather broad, round or truncate, sometimes with minute erect lateral projection. Spores about $42 \times 4 \mu$. Perithecia $100-130 \times 30-40 \mu$. Antheridia $15 \times 4 \mu$. Appendages $15-22 \times 5-6 \mu$. Total length to tip of perithecium $200-275 \times 60$ $85 \mu$.

On Amblyscelis sp., Nos. 2565 and 2571, Kamerun.

A rather large pale species, somewhat similar to $R$. Papuana and $R$. circumdata in general appearance, but distinguished by numerous points of difference; for example in the production of appendiculate cells from the distal cells of the median series. In a number of specimens certain appendiculate cells, irregularly scattered, may become blackened abnormally, and other cells may occasionally be similarly modified.

\section{Rickia Ancylopi nov. sp.}

Nearly symmetrical, wholly suffused with dirty brown, except the hyaline contrasting appendiculate cells; darker or opaque in the region of the perithecium. Receptacle triseriate, the foot large broad and rounded, the basal cell evenly suffused with pale dirty brown, its pointed distal third or more intruded between the basal cells of the two marginal series: anterior series extending slightly further than the median series, consisting of usually fifteen obliquely superposed cells which are subequal and more or less deeply suffused, except the three uppermost; the latter nearly hyaline and small; all except one or two of the uppermost cutting off externally and distally one or two quite hyaline cells, which bear normal antheridia or appendages: posterior series similar to the anterior, its basal cell somewhat larger, and usually cutting off a single appendiculate cell; the three terminal cells smaller and hyaline; the two upper usually not associated with appendages; the well developed and wholly free base of the primary appendage, the two cells of which are subequal and separated by a slightly oblique septum, projecting outward above the terminal cell: median series consisting of usually fourteen cells, the five or six lying below the base of the perithecium subequal and each of about the same diameter throughout its length, except the uppermost, which 
is shorter broader and more deeply suffused; the group forming a straight jointed axis, somewhat constricted and darker at the septa; the cells beside the perithecium hardly distinguishable from it in the general suffusion of this region, the distal cell lying free beyond the base of the primary appendage, but not reaching higher than the base of the perithecial tip. Appendages mostly ovoid, shorter than the numerous somewhat divergent, hyaline, rather stout antheridia; the well distinguished, stout, purplish necks of which, are usually curved slightly outward. Perithecia nearly symmetrical, not quite median, erect or very slightly tilted, becoming deeply suffused with reddish brown; the margins nearly straight, hardly distinguished from the adjacent marginal cells; the tip well distinguished, very short and broad, distally blackened below the broad flat contrasting hyaline apex. Spores about $28 \times 3 \mu$. Perithecia $60-66 \times 12-18 \mu$. Appendages $54 \times 3.6 \mu$. Antheridia $11 \times 4 \mu$. Total length to tip of perithecium $145-160 \times 32-36 \mu$.

On the elytra of Ancylopus bisignatus Gerst, No. 2562, Kamerun.

A species very readily distinguished by the peculiar appearance of the portion of the receptacle lying below the perithecium, where the median cell-series forms a clearly defined suffused bamboo-like axis, to the ends of the segments of which the suffused or blackened cells of the marginal series are sometimes, though not always, adjusted in almost perfectly symmetrical pairs, having the appearance of broad dark appendages projecting outward from them and ending in a more deeply blackened tooth-like termination which subtends the slight convexity on which the appendiculate cell rests. Like other suffused forms, this species recalls in its general appearance that of some forms of Rhachomyces.

\section{Rickia Episcaphae nov. sp.}

Receptacle triseriate, symmetrical below the perithecium and of equal width almost to the basal pair of marginal cells, whence it tapers rather abruptly to the foot; the basal cell hyaline, somewhat broader distally, and slightly intruded between the two cells above it; which are similar, symmetrically paired, and subtriangular, more or less completely and deeply suffused with reddish brown, the suffusion often involving to some extent the cells immediately above: median series consisting of from twelve to sixteen cells; the fourteen to sixteen lying below the perithecium very regular in form and size, somewhat longer than broad, subrectangular with rounded angles, their walls, especially, 
more or less faintly suffused with dirty brownish; the five or six distal ones, lying beside the lower third of the perithecium, much smaller and subequal: anterior series consisting of about twenty-five to twentynine cells, those below the perithecium subequal, subtriangular, hyaline or faintly and irregularly suffused inwardly with dirty yellowish brown; the six to eight distal cells evenly suffused with yellowish brown; small, rounded; the upper somewhat smaller and extending to about two thirds or three quarters of the total length of the perithecium; all the cells, except two or three of the terminal ones, cutting off one to three superposed cells, which bear copious appendages and scanty antheridia: posterior series similar to the anterior, ending beside the distal cell of the median series, the basal cell of the primary appendage lying just above their terminations, in contact with the perithecium, and not distinguished from the cells below, its distal cell short, broad, subtriangular, free, diverging laterally. Antheridia very scanty, usually only one or two on the anterior series, opposite the base of the perithecium; about as long as the hyaline, stout, rather irregular appendages, purplish; the neck more deeply colored, long, slender, and abruptly distinguished. Perithecia usually esect and straight, the insertion slightly lateral, rich purplish brown, the surface more or less distinctly mottled; one half or more of the posterior, and one fourth of the anterior margin free; the enclosed portion narrower; the tip broadly conical, the margins slightly convex, short, abruptly distinguished, subtended by a paler or almost hyaline line; the apex flat and broad, hyaline, the lip-cells projecting slightly. Spore about $50 \times 5 \mu$. Perithecia $80-100 \times 27-30 \mu$. Antheridia $16 \times 4 \mu$. Appendages 10-20 $\times 2 \mu$. Total length to tip of perithecium 310-425 $\mu$.

On Episcapha antennata, Nos. 2391 and 2392, Mindanao, Philippines.

Numerous individuals have been examined of this large and handsome species which is most nearly related to $R$. Coptengalis, from which it differs in the more highly developed receptacle, the relation of its perithecium to the latter, and the form of its tip, as well as in the very scantily developed antheridia.

\section{Rickia Eumorphi nov. sp.}

Straight or slightly curved, hyaline and rich brown, contrasting; large, long, broader in the region of the perithecium, below which it tapers very gradually, or hardly at all, to the basal cells of the marginal series. Receptacle indeterminate, triseriate; the basal cell hyaline, 
abruptly narrower and intruded somewhat between the two nearly opaque cells above it, the deep suffusion of which may extend downward beside its extremity in hooked prolongations: anterior series wholly or partly involved by the opacity which makes the structure of the median region quite indistinguishable, the distal cells beside the perithecium usually hyaline or translucent; consisting of from thirty-four to forty-eight similar cells, and extending to, or somewhat above, the base of the perithecial tip; all except the small terminal one cutting off from one to usually not more than three small hyaline cells, bearing antheridia or appendages: posterior series similar to the anterior and consisting of about the same number of cells, terminating somewhat lower down than the anterior; its distal cell lying beside that of the median series, the two bearing distally between them the free relatively long and narrow base of the primary appendage, the somewhat larger lower cell of which is separated from the upper by a slightly oblique septum: median series wholly opaque and indistinguishable, except four or five of its distal cells; the three or four terminal ones being hyaline. Antheridia numerous, conspicuous, the cylindrical, purplish brown, usually slightly curved necks often longer than the slightly inflated venter. Appendages often shorter, rarely longer, than the antheridia, hyaline, subcylindrical. Perithecia rather long and narrow, sometimes slightly tilted, the basal portion suffused with purplish brown to somewhat above the middle, deeper on the posterior side, the distal portion tapering slightly and subsymmetrically to the coarse blunt apex; its lower half, or less, abruptly hyaline or nearly so; its upper half or more abruptly and deeply suffused, the suffusion extending lower than the short broad tip proper, which is not distinguished except by its lateral deeper suffusion; a rounded translucent brownish area below and including the median pore. Spores about $40 \times 3.6 \mu$. Perithecia 90-100 $\times 20-24 \mu$. Antheridia $20 \times 4 \mu$. Appendages $80-20 \times 4 \mu$. Total length to tip of perithecium $230-400 \times 40-55 \mu$.

On Eumorphus cyanescens Gerst., No. 2390, Mindanao, Philippines.

A fine and very striking species, most nearly allied to $R$. Coptengalis and $R$. Episcaphae, and resembling $R$. Berlesiana in its axial suffusion, which is much more extensive than in this species. 
Rickia nigrescens nov. sp.

Nearly symmetrical, tapering slightly below to a rather slender base, more or less deeply suffused with blackish brown. Receptacle triseriate, the basal cell nearly hyaline below, distally somewhat broader, deeply suffused, and hardly distinguishable from the two short paired basal cells of the marginal series, which become quite opaque: anterior series consisting of about fourteen suffused cells, not differing greatly in size, those in contact with the perithecium slightly smaller, all but the opaque basal one cutting off distally and externally one, or two, small nearly hyaline cells, in the latter case lying side by side and not superposed, which bear appendages or antheridia; the latter mostly from the mid-region: posterior series similar to the anterior, extending about as far, and ending in the base of the primary appendage: median series hardly intruded between the second pair of marginal cells, consisting of usually twelve cells, the upper somewhat smaller; the cells of all the series more or less similar, rather small, subisodiametric, or but slightly longer than broad, arranged nearly symmetrically in tiers, of which there are usually nine or ten between the basal cell and the base of the perithecium which is subtended by a well defined stalk-cell. Perithecium slightly more than half free on both sides, deeply suffused with olive brown; straight, erect, nearly symmetrical; the distal half conical; the tip hardly distinguished; the apex hyaline small, rounded. Antheridia somewhat appressed, straight, or the purplish neck slightly curved outward. Appendages hyaline, stout, cylindrical, becoming somewhat gelatinous and coherent, soon disappearing. Spores about $35 \times 2.5 \mu$. Perithecia $70-78 \times 24 \mu$. Appendages $20 \times 4.5 \mu$. Antheridia $12 \times 4 \mu$. Total length to tip of perithecium $150-190 \times 32-35 \mu$.

On the elytra of Coproporus hypocyploides Bernh., No. 1830, Sarawak, Borneo; No. 2416, Manila, Philippines.

A deeply suffused species which at first sight suggests a form of Rhachomyces, the receptacle above the basal cell being rather slender and about the same width nearly to the base of the perithecium. It is closely allied to the following species from which it differs in color, in the greater number of tiers below its perithecium, the more regular arrangement of its cells, and also in the almost sharply conical free portion of the perithecium. 
Rickia pallescens nov. sp.

Erect, straight, somewhat soiled or stained with brownish above. Receptacle triseriate, basal cell rather large, distally slightly broader and not intruded between the basal cells of the marginal series; which are similar to the basal cell, or the posterior slightly longer, and subsymmetrically paired as are the two shorter broader marginal cells immediately above them: anterior series consisting of usually twelve superposed cells becoming smaller distally, and in contact with somewhat more than half the anterior margin of the perithecium; all the cells, except the lowest cutting off, the subbasal one, the rest several small appendiculate cells distally and externally; which, in the latter case, lie side by side; those of the mid-region bearing for the most part antheridia, the rest mostly minute appendages: posterior series similar to the anterior and extending nearly as far upward, terminating in the primary appendage which, with its base, is hardly distinguishable from the secondary ones associated with it: median series consisting of eight or nine cells, the three lowest larger, the rest becoming gradually smaller; the distal or subdistal usually cutting off an appendiculate cell or bearing an appendage directly; the series not extending quite as far upward as the other two. Antheridia numerous and typical, rather large, appressed or somewhat divergent, asymmetrical; the necks somewhat tapering and tinged with dirty purplish brown, more or less distinctly curved outward. Perithecium erect, straight, deeply suffused with dirty olive brown; rather long and narrow, free on both sides from just below the tip; which is abruptly distinguished, straight and stout, the apex slightly distinguished, subhyaline, broad, flat, symmetrically rounded. Spores about $30 \times$ $2.8 \mu$. Perithecia $68-75 \times 18-22 \mu$. Antheridia $15 \times 4 \mu$. Total length to tip of perithecium $150-200 \times 35-45 \mu$. P. I.

On the legs of a small species of Coproporus, No. 2543, Manila,

Closely allied to $R$. nigrescens of which it may prove only a variety. It differs in its nearly hyaline receptacle and pale perithecium which is more completely surrounded by the former: the tip and apex broader and differently shaped.

\section{Rickia Circopis nov. sp.}

Straight, erect, slightly asymmetrical. Receptacle triseriate, hyaline; basal cell rather short, distally broader, hardly intruded be- 
tween the somewhat larger and longer basal cells of the two marginal series: anterior series extending slightly higher than the two others, consisting of usually ten successively smaller cells, or the four lower subequal, the lowest smaller than that of the posterior series, all the rest cutting off one, sometimes two superposed small cells distally and externally, which bear either appendages or antheridia: posterior series similar to the anterior, consisting usually of nine cells surmounted by the small base of the primary appendage, the upper cell of which is free: median series consisting normally of eight cells, the lowest lying wholly above the second pair of marginal cells, the second somewhat larger. Appendages very small, rounded, or but slightly longer than broad, antheridia normal, hyaline, curved outward, the necks rather stout and not abruptly distinguished. Perithecia pale straw-colored, nearly symmetrical, straight, erect, somewhat less than half free on both sides; the tip stout, abruptly distinguished, tapering to the minute papillate apex; the base subtended by a well defined stalk-cell. Perithecia $60-80 \times 20-24 \mu$. Appendages $3.5-5.5 \times$ $3.5 \mu$. Antheridia $12 \times 3.5 \mu$. Total length to tip of perithecium $135-155 \times 40-45 \mu$.

On the inferior thorax of Circopes Philippinensis Grouv., No. 2274, Kamerun.

Somewhat similar in general appearance to $R$. pallescens but distinguished by the different relation of its appendiculate cells, the form color and relations of it perithecia, as well as in other respects.

\section{Rickia Episcaphulae nov. sp.}

Hyaline, asymmetrical, subsigmoid. Receptacle triseriate; basal cell large, longer than the cells next above it, between which it is but slightly intruded: anterior series consisting of about thirteen cells of irregular size and outline; the lower longer; the middle broader and shorter; the six or seven distal cells which lie beside the perithecium, becoming smaller, irregular and broader in proportion to their length; the lower three usually without appendages; the rest cutting off single relatively large cells, which bear antheridia or appendages: posterior series similar, consisting of nine or ten cells; the basal longer than that of the anterior, and separating an appendiculate cell, as do all the others, except the second, third and last; which, with the corresponding cell of the median series, subtends the base of the primary appendage: median series consisting of nine or ten cells, similar in general to 
those of the other series; the lowest not intruded between the second pair of marginal cells; the four or five distal ones smaller, and lying beside the perithecium. Distal cell of the base of the primary appendage free, divergent, short and broad; longer than the somewhat flattened basal cell. Appendages short and stout, somewhat inflated. Antheridia large and slightly curved, with relatively short stout necks. Perithecia rather narrow, curved toward the posterior side and of nearly uniform diameter; the tip, only, free, except at its abruptly spreading base; the apex not distinguished, broadly rounded. Perithecium $50 \times 12-14 \mu$. Appendages $10 \times 4 \mu$. Antheridia $12-16 \times$ $4-5 \mu$. Total length to tip of perithecium $160-180 \times 36-40 \mu$.

On Episcaphula sp., No. 2446, Kamerun.

Two specimens, only, have been examined, neither of them in very good condition. The species seems well distinguished, however, from its subsigmoid habit, and the protruding finger-like tip of its perithecium.

\section{Rickia Saulae nov. sp.}

Receptacle triseriate, hyaline, becoming suffused with dirty brownish distally; basal cell abruptly bent, short and stout: anterior series consisting of eight cells extending to or slightly beyond the middle of the perithecium, the second and third more than twice as long as broad, all somewhat rounded, becoming smaller distally, the upper three in contact with the perithecium and overlapping it so as to be hardly visible externally, all cutting off small cells distally and externally, which bear appendages or normal antheridia; one to three of the middle members cutting off two such cells, which are asymmetrically related, lying side by side or partly superposed: posterior series similar to the anterior in number, and extending to about the same point on the perithecium; the distal cells so placed that they do not appear externally, lying obliquely opposite the corresponding cells of the anterior series; the primary appendage and its base not clearly distinguishable: median series consisting of only four visible cells, three lying below the perithecium, the two lower much longer, the lowest intruded between the second pair of marginal cells nearly to their bases. Perithecium relatively large, nearly as broad as the receptacle, becoming rather deeply and somewhat unevenly suffused with brown, the tip and base paler; median, slightly tilted inward, nearly symmetrical; subtended by a distinct stalk-cell; stout, the margins more or less continuously curved to the broad blunt apex; 
neither the tip nor the apex definitely distinguished. Antheridia scanty, with relatively long straight slender necks. Spores about $28 \times 3 \mu$. Perithecia $60-65 \times 25-28 \mu$. Total length to tip of perithecium about $150 \mu$. Antheridia $16 \times 4 \mu$.

On Saula sp., No. 2387, Mindanao, P. I.

A species distinguished by its large, broad, deep yellowish brown perithecium, which is almost as broad as the receptacle below it; its posterior margin appearing to be wholly free, owing to the fact that the median and posterior series extend upward on the lateral (left) surface, and lie wholly within its margin, when it is viewed sidewise.

\section{Rickia Phalacri nov. sp.}

Long, straight, erect. Receptacle triseriate, tapering very gradually to the base, with a faint axial brownish suffusion; the basal cell small and more or less suffused with purplish brown; the two lower cells of the marginal series small, somewhat unequal; all the series consisting of usually twelve cells each, those of the median series mostly subrectangular; the cells between the basal pair and the base of the perithecium arranged in oblique tiers of three cells each: the cells of the marginal series, with the exception, usually, of the anterior one, cutting off relatively large cells bearing antheridia or appendages; the two small uppermost cells of the anterior, and of the median series, in lateral contact with the very base of the perithecium; the posterior series terminating in the rather conspicuous slightly divergent base of the primary appendage. Antheridia and appendages somewhat appressed, the former rather scanty, convex on the inner side, and slightly curved outward. Perithecium laterally placed above the posterior and median cell-series, more or less evenly suffused with rich purplish brown; straight, erect, relatively long and narrow, nearly symmetrical, subtended by a well defined stalk-cell; the tip well distinguished, short broad, tapering to a rather broad hyaline, subtruncate, symmetrical apex. Spores about $28 \times 2.5 \mu$. Perithecia 58-65 $\times 16-18 \mu$. Appendages $9-11 \times 3.5 \mu$. Total length to tip of perithecium $135-175 \times 18-20 \mu$.

On the elytra of Phalacrus sp., No. 2495, Manila, P. I.

A pretty species well distinguished by its usually straight, rather elongate receptacle, on which the rich brown perithecium is inserted a little at one side. 


\section{Rickia Sarawakensis nov. sp.}

Asymmetrical. Receptacle hyaline, triseriate, both the foot and the basal cell relatively very large, the latter geniculate below, distally broader and rounded: anterior series consisting of two superposed cells, the upper smaller and separated from the base of the perithecium by a small well defined stalk-cell: both cutting off two cells distally and externally, which bear antheridia or appendages of the normal type: posterior series consisting of four cells, which may be subequal; all cutting off two cells which bear antheridia or appendages; the uppermost corresponding to the lower cell of the base of the primary appendage, larger, almost wholly free beside the base of the perithecium, cutting off an appendiculate cell externally and followed distally by the upper cell which is bent inward toward the perithecium: median series consisting of two superposed cells, the lower larger, but slightly intruded between the second pair of marginal cells; the upper very small, lying just beside the base of the ascigerus cavity. Perithecium wholly free, its insertion slightly oblique, rather short and stout, rosy brown, usually subsigmoid; the tip, which is not at all distinguished, bent outward slightly; the small hyaline truncate apex bent abruptly upward or inward. Spores about $28 \times 2.8 \mu$. Perithecia $45 \times 19 \mu$. Appendages $10 \times 4 \mu$. Antheridia $10 \times 3.5 \mu$. Total length to tip of perithecium $95 \times 10-12 \mu$.

On elytra of Phalacrus (?) sp., Sarawak, Borneo, No. 2371.

A small and simple species clearly distinguished by its free rosy brown perithecium. It is one of the few species in which the lower cell of the base of the primary appendage cuts off an appendiculate cell. The body of the receptacle consists of an unusually small number of cells, for a species of this normal type, which do not in general differ greatly in size, being mostly somewhat longer than broad and rather irregularly rounded in outline.

\section{Rickia Parasiti nov. sp.}

Hyaline, relatively long and narrow in general habit. Receptacle triseriate, the basal cell relatively long and slender, but slightly broader at the apex which is only slightly if at all intruded between the cells above it: anterior series consisting of three, or usually four, superposed cells; the lowest larger, twice as long as broad; the others successively 
smaller or subequal; each, or the two upper, only, cutting off distally and externally one, rarely two, superposed small cells which bear either short appendages, which are subtended by a blackened septum; or subulate sessile antheridia, not distinguished either by a constriction or a blackened septum at the base; the upper cell and its antheridia in oblique contact with the base of the perithecium: median series consisting of eight or more, often nine, cells; the lowest larger, lying below the base of the perithecium, the rest united to its inner margin; the distal one often somewhat larger, the rest rather small, becoming subequal and rounded: posterior series nearly straight or but slightly convex externally, consisting of eight or more, often nine, superposed cells, some or all of which may cut off distally and externally small appendiculate cells bearing subcylindrical usually appressed appendages; the lowest cell somewhat longer than the corresponding cell of the anterior series, and subtriangular in form; the rest subequal or slightly smaller distally, the series ending in the two-celled base of the primary appendage which may be obliquely or almost horizontally placed, and is thus variably divergent; its upper cell very small, its lower nearly uniform with the other cells of the series, its base opposite the distal cell of the median series. Perithecium erect, tapering from a rather broad base, the outer margin free, slightly concave, the tip slightly distinguished; the apex, only, free on the inner side, slightly bent inward, distally broad, slightly sulcate. Spores about $25 \times$ $2.5 \mu$. Perithecia 45-60 $\times 18-20 \mu$. Appendages $9-11 \times 3 \mu$. Basal cell $35 \times 9 \mu$. Total length to tip of perithecium $90-125 \times$ 26-36 $\mu$.

On Parasitus sp., No. 2796, Mexico, M. C. Z. (Mann).

Although very different in general appearance, this species is most nearly allied to $R$. minuta; which is, however, very readily distinguished by the crest-like curvature of its posterior cell-series and its bladder-like appendages, as well as by other points of difference.

\section{Rickia Gryllotalpae nov. sp.}

Hyaline, rather elongate, strongly or slightly sinuous, tapering gradually below to the foot. Receptacle triseriate, the basal cell relatively long, slightly intruded distally, slightly and abruptly swollen above the foot: anterior series consisting of ten to eleven subequal cells, somewhat longer than broad, which cut off one or more, often two, almost vertically superposed cells bearing appendages; while the 
terminal, and sometimes the subterminal, bear single pointed antheridia, the upper more or less appressed externally beside the base of the perithecium: posterior series similar to the anterior, consisting of eleven or twelve cells all cutting off cells which bear appendages only; the series surmounted by the free base of the primary appendage which diverges almost at right angles, its basal cell cutting off a secondary appendiculate cell distally on the lower, or sometimes on the upper side: median series consisting of usually twelve cells, the upper four or five extending beside the base of the perithecium and beyond the insertion of the base of the primary appendage; the basal cell longest, and intruded between the third pair of marginal cells. Appendages strictly marginal, of the usual type; becoming faintly tinged with yellowish brown, stout, rather short, usually broader above the constricted base: the primary appendage usually more or less persistent and smaller. Antheridia usually single, quite hyaline, spinelike, without differentiation between the neck and venter, or the usual constricted and suffused base. Perithecium almost free; its inner margin, only, in contact for a short distance with the terminal cells of the median series; erect, or tilted slightly inward, straight, somewhat asymmetrical; the outer margin more convex; the tip more or less clearly distinguished, tapering subsymmetrically to the rather blunt truncate apex. Spores about $35 \times 3 \mu$. Perithecia $75-85 \times 24-27 \mu$. Antheridia $15 \mu$. Appendages $12-20 \times 7.5 \mu$. Total length to tip of perithecium $230-325 \times 28 \mu$.

On the wing tips of Gryllotalpa sp., No. 2155, U. S. Nat. Mus.; Africa, (Mearns).

Several specimens have been examined all in good condition. The antheridia are similar in type to those of $R$. Lycopodinae and $R$. minutus and occur in the same position as in the last mentioned species. The production of one or more secondary appendiculate cells from the base of the primary appendage, is unusual.

\section{Rickia Lycopodinae nov. sp.}

Rather broad distally, tapering below; the hyaline margins contrasting with the deep black-brown or opaque axis and perithecium. Receptacle triseriate; the foot round, and as large as the thick-walled basal cell, which is distally intruded so as nearly to separate the two basal cells of the marginal series: anterior series consisting of about twelve to fifteen cells, mostly short broad and obliquely superposed; 
all, with a few irregularly distributed exceptions, cutting off distally and externally single cells which may be even larger in size, and bear either antheridia or appendages; the terminal cell broad, flattened, often suffused, and forming a straight, very oblique, clearly defined base to the perithecium: posterior series consisting of from about sixteen to twenty cells; similar to the anterior, and terminating in the basal cell of the base of the primary appendage, which lies about opposite the middle of the perithecium; the cells of both marginal series often tending to become vertically divided: median series consisting of about fourteen to eighteen cells which become deeply suffused with blackish brown, the suffusion becoming opaque, involving to some extent the adjacent cells and continuous with that of the perithecium; the cells rather regular and longer than broad, except the six or seven distal ones which lie beside the perithecium, extending to the base of its tip; about three of the terminal cells externally free beyond the base of the primary appendage; the free upper subconical cell of which is larger than the basal cell and diverges laterally. Appendages thick-walled, inflated, straight and stout, somewhat irregular. The antheridia numerous, sometimes more so than the appendages. Perithecia more or less opaque, asymmetrical, short and stout; the base straight and oblique; the tip well distinguished, hyaline or paler, bent abruptly sidewise so that it is partly concealed in side view, tapering to the broadly rounded undifferentiated apex. Perithecia $55 \times 24-27 \mu$. Free portion of antheridia 15-20 $\mu$. Appendages mostly $7-10 \times 5.5 \mu$. Total length to tip of perithecium $125-156 \times$ 40-45 $\mu$.

On legs of Lycopodina sp.; M. C. Z., No. 2801, Madagascar (Wul$\sin )$.

A striking species, remarkable for the fact that its numerous antheridia belong to the type present in $R$. minuta and several other species, being partly immersed and without the usual characteristic blackened insertion. The general habit, however, is rather that of the more typical forms of the genus, although it is somewhat anomalous in its tendency to show abnormal vertical divisions in its marginal cells, which may be smaller than the appendiculate cells separated from them above.

\section{Rickia Zirophori nov. sp.}

Receptacle triseriate, of about the same diameter from the base of the perithecium to that of the median cell; uniformly hyaline to pale 
yellowish, usually elongate, straight or sometimes variously bent. Basal cell very small, sometimes almost obliterated by the intrusion of the basal cell of the anterior series: anterior series consisting of two elongate cells; the upper shorter and separated below by a septum running obliquely inward and downward, cutting off distally a marginal series of four to six closely associated appendiculate cells; the lower slightly prominent distally, just below the septum, and sometimes cutting off one or two appendiculate cells at this point: posterior series similar, the upper cell shorter than that of the anterior, its margin often entirely occupied by a marginal row of small closely associated appendiculate cells, the uppermost usually lying between the perithecium and the base of the primary appendage, which is small and short, its basal cell slightly intruded and much smaller than the somewhat rounded distal cell: median series consisting of a very small cell lying beside the base of the perithecium and a greatly elongated cell which extends to within a short distance of the base of the marginal cells which are in contact below it and are of about the same uniform diameter throughout. Appendages of the usual type, cylindrical or slightly tapering. Antheridia rarely developed, the antheridial cells apparently becoming free in small groups. Perithecia almost wholly free, long, narrower toward the base, the margins slightly convex and nearly symmetrical, nearly erect or slightly divergent outward, the base oblique, the tip more or less distinguished, tapering considerably, and usually symmetrically, to the rather narrow bluntly rounded apex. Spores about $35 \times 3.5 \mu$. Perithecia $116-$ $136 \times 27 \mu$. Appendages $40 \times 4 \mu$. Total length to tip of perithecium $300-400 \times 34-40 \mu$.

On the legs and inferior surface of Zirophorus sp., No. 2802, vicinity of Port of Spain, and at Arima, Trinidad, B. W. I.

This species is a third well marked representative of the section to which $R$. marginata and $R$. Lispini belong, and is very nearly allied to the latter, from which it differs in its much greater size and elongate habit, and differently shaped practically free perithecium. In a few individuals, in which the perithecium has aborted, the appendages appear to be in some instances replaced by groups of three or four short free antheridia, as in R. Leptochiri and some others. Although the host is not uncommon in Trinidad, the parasite appears to be decidedly rare. 


\section{$2 \mathrm{BHL}$ Biodiversity Heritage Library}

Thaxter, Roland. 1916. "New or critical species of Chitonomyces and Rickia." Proceedings of the American Academy of Arts and Sciences 52, 1-54.

View This Item Online: https://www.biodiversitylibrary.org/item/22134

Permalink: https://www.biodiversitylibrary.org/partpdf/246943

\section{Holding Institution}

MBLWHOI Library

\section{Sponsored by}

MBLWHOI Library

\section{Copyright \& Reuse}

Copyright Status: NOT_IN_COPYRIGHT

This document was created from content at the Biodiversity Heritage Library, the world's largest open access digital library for biodiversity literature and archives. Visit BHL at https://www.biodiversitylibrary.org. 